WORKING PAPER \#441

Comments Welcome

PRINCETON UNIVERSITY

INDUSTRIAL RELATIONS SECTION

JUNE 2000

http://www.irs.princeton.edu/pubs/working_papers.html

\title{
Moving to Opportunity in Boston: Early Results of a Randomized Mobility Experiment
}

\author{
Lawrence F. Katz \\ Harvard University and NBER \\ Jeffrey R. Kling \\ Princeton University and NBER \\ Jeffrey B. Liebman \\ Harvard University and NBER
}

June 6, 2000

The authors thank the U.S. Department of Housing and Urban Development, the National Institute on Aging, National Bureau of Economic Research, and Harvard University for research support. The authors are grateful to Yvonne Gastelum for collaborating on qualitative interviews in Spanish, Ying Qian for conducting pilot survey interviews and for compiling family contact information, Adriana Mendez for translating the survey into Spanish, Humberto Reynosa for editing the Spanish translation, and to Patrick Wang, Beth Welty and Lorin Obler for excellent research assistance. We thank all of the members of the MTO teams at MBHP, BHA, Abt and Westat for making our research possible, and Carol Luttrell for facilitating our access to administrative data. We have benefitted from conversations with numerous colleagues. We are particularly indebted to Josh Angrist, Deborah Belle, Xavier Briggs, Janet Currie, David Ellwood, Judie Feins, Richard Frank, Edward Glaeser, John Goering, Christopher Jencks, Ron Kessler, Alan Krueger, Edward Lazear, Willard Manning, Joe Newhouse, Larry Orr, Mike Piore, Jim Rebitzer, Marta Tienda, Julie Wilson, and Aaron Yelowitz for their suggestions.

E-mail addresses: 1katz@harvard.edu, kling@princeton.edu, jeffrey_liebman@harvard.edu 


\title{
Moving to Opportunity in Boston: Early Results of a Randomized Mobility Experiment
}

June 6,2000

\begin{abstract}
This paper examines the short-run impacts of a change in residential neighborhood on the well-being of low-income families, using evidence from a program in which eligibility for a housing voucher was determined by random lottery. We examine the experiences of households at the Boston site of Moving To Opportunity (MTO), a demonstration program in five cities. Families in high poverty public housing projects applied to MTO and were assigned by lottery to one of three groups: Experimental - offered mobility counseling and a Section 8 subsidy valid only in a Census tract with a poverty rate of less than 10 percent; Section 8 Comparison - offered a geographically unrestricted Section 8 subsidy; or Control - offered no new assistance, but continued to be eligible for public housing.

Our quantitative analyses of program impacts uses data on 540 families from a baseline survey at program enrollment, a follow-up survey administered 1 to 3.5 years after random assignment, and state administrative data on earnings and welfare receipt. 48 percent of the Experimental group and 62 percent of the Section 8 Comparison group moved through the MTO program. One to three years after program entry, families in both treatment groups were more likely to be residing in neighborhoods with low poverty rates and high education levels than were families in the Control group. However, while members of the Experimental group were much more likely to be residing in suburban communities than were those in the Section 8 group, the lower program take-up rate among the Experimental group resulted in more families remaining in the most distressed communities. Households in both treatment groups experienced improvements in multiple measures of well-being relative to the Control group including increased safety, improved health among household heads, and fewer behavior problems among boys. Experimental group children were also less likely to be a victim of a personal crime, to be injured, or to experience an asthma attack. There are no significant impacts of either MTO treatment on the employment, earnings, or welfare receipt of household heads in the first three years after random assignment.
\end{abstract}




\section{Introduction}

Poverty in the United States has become increasingly concentrated in high poverty areas. For example, between 1970 and 1990, the percentage of poor persons in metropolitan areas living in census tracts with a poverty rate of 40 percent or more increased from 12 percent to 18 percent (Jargowsky 1997). Federal housing policies which funded large high-rise public housing developments in central cities during the 1950s and 1960s (Von Hoffman 1996) and which in the 1980s targeted assistance on the poorest eligible households (Epp 1998) are likely to have contributed to this trend.

The concentration of poverty in inner cities, along with recent increases in residential segregation by family income and the persistence of residential segregation by race in U.S. metropolitan areas (Cutler, Glaeser, and Vigdor 1999; Jargowsky 1996), has potentially disturbing implications because of evidence that residential neighborhoods are associated with both the current well-being and future opportunities of residents. In particular, children who grow up in poor neighborhoods fare substantially worse on a wide variety of outcomes than those who grow up with more affluent neighbors even in studies that include detailed controls for family income and background characteristics (e.g., Brooks-Gunn, Duncan, Klebanov, and Saland 1993).

Many analysts conclude from such findings that residential location greatly affects access to opportunity through peer influences on youth behavior and through a variety of neighborhood characteristics correlated with neighborhood wealth -- such as school quality and safety from crime. The willingness of families to pay substantial house price and rental premia to move to wealthier neighborhoods and gain access to better schools strongly suggests that typical citizens believe that neighborhood and school social composition affect their children's life prospects. ${ }^{1}$ Furthermore, assumptions of causal neighborhood and peer effects are central to theories of social capital (Coleman 1988) and to models of human capital externalities and growth (Benabou 1993; Lucas 1988), and are often used to justify government provision of housing assistance rather than unrestricted cash grants for low income families (Quigley 1980).

Although existing empirical studies and the perceptions and actions of parents are suggestive of the importance of neighborhoods, the estimation of the causal effects of neighborhoods is fraught

${ }^{1}$ Black (1999) provides convincing evidence of parents' willingness to pay for higher public school quality by comparing house prices for comparable homes in the same neighborhoods on different sides of the borders between adjacent elementary school attendance districts for suburban areas in Massachusetts. 
with difficulties. ${ }^{2}$ Observed differences in youth outcomes by type of neighborhood could reflect unmeasured differences in family background. The reduction in the magnitude of estimated neighborhood effects when detailed controls for family background are included suggests that with even better controls estimates of neighborhood effects might be further reduced (Corcoran, Gordon, Laren, and Solon, 1992). ${ }^{3}$ But the difficulty of measuring neighborhood attributes and of defining appropriate peer groups may lead to underestimates of neighborhood and peer influences.

These estimation problems would be greatly reduced if we could compare the outcomes of children from truly comparable families growing up in different types of neighborhoods. The ideal evaluation design would be the random assignment of families of interest to different neighborhoods. Housing mobility programs in which some low-income inner-city families are given assistance in moving to less-segregated, wealthier, and/or suburban locations can approximate such a design if access to such assistance is randomly assigned. The Gautreaux program, which has operated in the Chicago metropolitan area since 1976, is suggestive of the potential of learning about neighborhood influences from housing mobility programs. ${ }^{4}$ Quasi-experimental comparisons of the household heads and the children of a sample of suburban and urban movers in the program suggest that moving to the suburbs greatly increased youth educational attainment and labor market outcomes and modestly improved mothers' employment rates relative to moving to other parts of the city

\footnotetext{
${ }^{2}$ See Duncan, Connell, and Klebanov (1997), Jencks and Mayer (1990), and Manski (1993) for detailed discussions of conceptual and practical issues in the estimation of neighborhood effects.

${ }^{3}$ Recent research has attempted to better control for family background and to better address the issue of selectivity of residential location within a metropolitan area (MSA). Aaronson (1998) examines families that relocate and compares siblings that grow up in different neighborhoods. Aaronson finds substantial negative effects of neighborhood high-school dropout rates on individual dropout rates in sibling difference models. But differences in sibling outcomes could reflect changes in family circumstances driving residential moves. Cutler and Glaeser (1997) compare outcomes for black and white youths across MSAs by the extent of racial residential segregation without conditioning on residential location within an MSA and find substantially lower relative socioeconomic outcomes for black youth in more segregated MSAs. Currie and Yelowitz (2000) argue that the correlation between living in a public housing project and poor outcomes may be spurious. They use an instrumental variables estimation strategy (where some families are quasi-randomly entitled to a larger unit based on the sex composition of their children) and find that boys in project households are less likely to have been held back in school.

${ }^{4}$ The Gautreaux program resulted from a Supreme Court consent decree in a racial discrimination lawsuit against the Chicago Housing Authority and the U.S. Department of Housing and Urban Development (HUD) filed on behalf of Chicago public housing residents. It provides low-income blacks originally residing in Chicago public housing with special housing certificates and assistance to move to neighborhoods in which the black population has a share of less than 30 percent, both in the suburbs and in other parts of the city of Chicago.
} 
(Rosenbaum 1995)..$^{5}$

The promising findings from the Gautreaux program helped motivate the development by HUD of an experimental housing mobility program that explicitly uses random assignment. This Moving to Opportunity (MTO) demonstration has been operating in five cities - Baltimore, Boston, Chicago, Los Angeles, and New York — since the fall of 1994. Families are eligible for participation in the demonstration if they have children and reside in public housing or project-based Section 8 assisted housing in a census tract with a 1990 poverty rate of 40 percent or more.

Interested eligible families who completed an application and survey were then selected from a waiting list and randomly assigned to one of three program groups: the Experimental group, the Section 8 Comparison group, and the Control group (Feins et al. 1994). Families in the Experimental group received a restricted Section 8 certificate or voucher that provides a rent subsidy which can be used to rent housing from private landlords, but only in a low poverty area (a census tract with under a 10 percent poverty rate in 1990). The Experimental group families also received counseling assistance from a local nonprofit organization to help them search for an apartment and adjust to a new neighborhood. Section 8 Comparison group members received a geographically unrestricted Section 8 certificate or voucher and no counseling assistance. The Control group families did not receive rental assistance vouchers or certificates, although their eligibility for continued project-based assistance was unaffected. The Experimental and Section 8 Comparison group members were given four to six months to submit a request for approval of an eligible apartment they would like to lease, and the apartment then had to pass a quality inspection.

By randomly assigning assistance in moving to wealthier neighborhoods, the MTO demonstration provides a unique opportunity both to assess the effectiveness of using housing mobility programs to move families to these neighborhoods and to measure the causal impacts of neighborhood attributes on family and youth outcomes for poor families. It also provides for a direct comparison of the two major forms of housing assistance for U.S. low-income families: project-based assistance and tenant-based assistance.

In this paper, we provide a comprehensive evaluation of the early impacts of the MTO

5 Even if moves through Gautreaux approximated random assignment (which has not been convincingly demonstrated), the very small sample of Gautreaux families who were interviewed by survey researchers some years later may have been unrepresentative in ways which could have influenced research results. 
demonstration on family well-being at the Boston site (measured about 2 years after program entry). ${ }^{6}$ We exploit the random-assignment design to produce these estimates through comparisons of the outcomes of the Experimental and Section 8 Comparison groups with those of the Control group. We combine information from field observations of the program, qualitative interviews with participants, data on Census tract characteristics linked to geocoded initial and current addresses of participants, responses to a follow-up survey of 520 MTO Boston participants, and state administrative data on earnings and public assistance receipt.

We begin in Section II by providing a more detailed description of the operation of MTO in Boston. We find that fear of crime was the primary reason participants wanted to move out of public housing at all five MTO sites. ${ }^{7}$ In section III, we present our econometric framework for analyzing neighborhood effects, and discuss the interpretation of parameters that can be estimated from the MTO experiment. In section IV we analyze mobility outcomes for the Boston families. We find that approximately 48 percent of the MTO group moved to private housing using the MTO vouchers as compared to 62 percent of the Section 8 Comparison group. Although the Experimental and Section 8 groups experienced similarly large positive effects on average neighborhood quality as measured by many census-tract characteristics, these averages mask important differences in the mobility patterns between the two treatment groups. Fewer Experimental group families managed to move out of their high-poverty origin neighborhoods, but those that did were much more likely than families in the Section 8 group to end up in suburban, low-poverty neighborhoods.

Next, we present estimates of the early impact of the treatments, focusing on outcomes that directly impact participant well-being in the short-term as well as on short-term outcomes that might provide mechanisms through which longer-term economic outcomes such as increased earnings and educational attainment could be brought about. In section $\mathrm{V}$, we analyze the impact of the program on children's health. We find that the program lead to a decline in behavior problems among boys

\footnotetext{
${ }^{6}$ Some preliminary results are also available for Baltimore and Los Angeles. For Baltimore, Ludwig, Duncan, and Hirschfield (2001) present evidence suggesting youth socialized in high-poverty neighborhoods may reduce their delinquency rate if their family moves through MTO. Hanratty, McLanahan, and Pettit (1998) find improvements in neighborhood safety for the both treatment groups in Los Angeles.

${ }^{7}$ Our qualitative interviews with Boston participants strongly reinforce this conclusion and indicate substantial concerns of these public housing residents with protecting themselves and their children from possibly arbitrary outbursts of violence. Kling, Liebman, and Katz (1996) provides a more detailed presentation of the findings from our qualitative interviews on participants perceptions of their neighborhoods.
} 
in both the Experimental and Section 8 Comparison groups, but has no discernable impact on girls. The Experimental group children also experienced fewer injuries and asthma attacks. One reason for the decline in behavior problems may have been an increase in neighborhood safety, which we document in Section VI. In Section VII, we analyze the impact of the program on the health of the household head. We find evidence that both MTO groups report their overall health was good or better. We fail to find evidence that potential movers became more socially isolated when they moved to their new neighborhoods, and indeed we find some evidence that the moves increased the degree of social trust among participants. In Section VIII, we examine welfare and employment, and find insignificant differences between all three MTO groups. Section IX concludes.

\section{The Nature of the MTO Experiment in Boston}

The MTO demonstration program presents an exciting opportunity to identify credibly the causal effects of a housing mobility program (and of neighborhoods) on a wide range of outcomes. Nonetheless, it is important to be explicit about the nature of the specific interventions that occurred at the Boston MTO site. Although concerns with the extent to which findings can be extended to different settings arise in the evaluation of any social experiment, our field work has made us particularly sensitive to potentially idiosyncratic features of the Boston MTO demonstration.

\section{The Program}

Each household assigned to the Experimental and Section 8 Comparison groups was issued a Section 8 subsidy that they could use to help pay the rent for an apartment in the private market, provided that the unit met HUD standards for quality upon inspection. The rental subsidy was roughly equal to the difference between the Fair Market Rent (FMR; set by HUD approximately at the $45^{\text {th }}$ percentile of local rents depending on bedroom size) and 30 percent of the tenant's income. In general, the households retain this subsidy as long as their income is sufficiently low (i.e., if 30 percent of their expected annual income is less than the FMR). ${ }^{8}$ Both treatment groups received briefings from HUD staff about program rules and about how to look for an apartment at the time of subsidy issuance.

\footnotetext{
${ }^{8}$ Households residing in public housing (non-movers in the treatment and control groups) also are expected to contribute 30 percent of their (adjusted) income to rent.
} 
The Experimental group members were also assigned a counselor from a local nonprofit (the Metropolitan Boston Housing Partnership, or MBHP). The counselors made home visits to review housing search strategies, explained which neighborhoods the subsides could be used in (providing a map marked with low-poverty Census tracts), helped program participants clear up bad credit histories, found apartment listings in newspapers, provided references to landlords, and sometimes drove participants to see promising apartments. Thus, the counselors played a very large role in determining the destination communities of the Experimental group members. ${ }^{9}$

The impact of this complex treatment may also have been affected by features of the Boston housing and labor markets during the period of study and by some changes in government policies that impacted the participating families. In particular, both housing vacancy rates and unemployment rates in the Boston area were very low (and falling) during the period of the study. In our qualitative interviews, we found that actual and potential changes to welfare rules and to Section 8 produced substantial anxiety among the MTO population. There was also a major change to Section 8 in the middle of MTO. For the first time, Section 8 landlords were permitted to require security deposits from prospective tenants. ${ }^{10}$ There were also major improvements during the study in the safety of some of the developments from which MTO families came. ${ }^{11}$

\section{The Data}

We gathered information about the program using five methods. We conducted field work to observe the operations of the program; completed open-ended qualitative interviews with a small random sample of program participants; undertook a follow-up survey of 520 MTO families on

\footnotetext{
${ }^{9}$ Participants were urged to assemble recommendations from past landlords and from neighbors saying that the participants were good tenants and that their children were not trouble makers. In some cases, MBHP provided small grants to households to enable them to purchase furniture or appliances for the new apartment. The counselors made at least one home visit in the year after the move to each family that leased up. Counselors sometimes resolved problems that arose for the participants in their new neighborhoods. For example, they mediated disputes between the participants and their landlords, and on a few occasions helped families deal with incidents of racial discrimination.

10 This requirement could be extremely burdensome for a tenant. For example, a security deposit of one month's rent for a tenant whose share of the rent was 10 percent (and HUD's share was 90 percent) would be equivalent to the amount of rent that the tenant would normally pay over 10 months.

${ }^{11}$ Indeed, one participant who moved to the suburbs told us that if the improvements in the projects had occurred earlier, she would not have applied for MTO and moved. She added, however, that she was grateful that she had moved and did not at all regret her decision to participate in the program.
} 
average about two years after program entry; and collected state administrative data on earnings and public assistance usage. Finally, we put together survey and administrative records on residential addresses, geocoded them, and merged them with the STF files of the 1990 Census of Population to describe the attributes of the neighborhoods of MTO families.

Because so much is going on inside the "black box" of the MTO treatments, we have attempted to supplement quantitative comparisons of outcomes by treatment status with qualitative research. Our field work included observing the administration of the baseline survey, attending intake sessions for families after randomization, accompanying counselors on home visits, and interviewing program staff. In our qualitative interviews, we performed 12 ninety-minute openended interviews with MTO household heads in the Experimental and Section 8 Comparison groups. The interviews covered the participants' experiences with the program, and their perceptions of their old and new (if they moved) neighborhoods. ${ }^{12}$

The sampling frame for the data used in this study consisted of household heads randomly assigned in the MTO program in Boston between October 1994 and May 1996. Over these 20 months, 540 families were enrolled; new cohorts were assigned approximately once a month, for an average of 27 families per month. We use data from two surveys. First, each household head completed a survey prior to enrollment in the MTO program, which we refer to as the "MTO Baseline Survey."

We also conducted our own survey, which we refer to as the "MTO-Boston Follow-up Survey." ${ }^{13}$ During June and July of 1997, we completed 340 interviews by telephone. Between November 1997 and April 1998, we completed an additional 180 interviews in person, for an overall survey response rate of 96.3 percent. ${ }^{14}$ Although MTO continued to enroll families in Boston

\footnotetext{
${ }^{12}$ The interviews took place in the respondents' homes, and were tape recorded. Interviews in English were jointly conducted by Kling and Liebman. Interviews in Spanish were conducted by Liebman and Yvonne Gastelum.

${ }^{13}$ The survey was written by our research team and administered in mixed modes (by telephone and in-person) by Westat Inc. The survey was administered in both Spanish and English. The complete survey is available at http://www.wws.princeton.edu/ kling/.

${ }^{14}$ We were unable to complete interviews with 20 household heads. In 13 of these cases, we located the household, but were unable to complete an interview because the sample member was deceased, avoided our interviewer, or refused to be interviewed. In 7 cases, we did not locate the household head, although in five of those cases we were in touch with friends or family members of the household head, and might ultimately have been able to locate the household head or other members of the MTO household with additional efforts.
} 
throughout 1996-97, we limited our sample to families who had up to 120 days to find a new residence and then at least nine months to have lived in the new residence. The monthly enrollments of new families and the different survey completion dates yield an average time between random assignment and the MTO-Boston Follow-up Survey of 2.2 years, with a range from 1 to 3.5 years.

\section{$\underline{\text { Characteristics of MTO Families }}$}

As shown in Table 1, the participants in all five MTO sites are largely female-headed households. The participants in Baltimore and Chicago are almost entirely African-American. The Boston, Los Angeles, and New York sites have more ethnically diverse groups of participants with over 40 percent Hispanics.

According to the Baseline Survey at the time of program enrollment, the main reason a majority of families (56 percent) wanted to move is fear of crime ("to get away from drugs and gangs"). Table 1 also reports that improvements in housing ("to get a bigger or better apartment") and school quality ("better schools for my children") were the next most important factors motivating moves. Employment concerns ("to get a job" or "to be near my job") were listed as the main reason to move by less than 2 percent of all participants. In contrast to the emphasis on crime as a motivation for wanting to move among current public housing residents in high poverty areas, participants in the Gautreaux housing mobility program in the late 1970s (Peroff et al. 1979, p. 114) indicated that good schools (34 percent) and quality of housing (26 percent) were more important considerations than crime (23 percent). The increased concern about crime among inner-city public housing residents likely reflects the increase in violent crime rates that occurred in many urban areas over this time period. The concern about crime may also have been the direct result of having been victimized recently. Across all five sites, over 23 percent of the household heads indicate that someone who lives with them had been beaten or assaulted in the past six months, and 10 percent had someone stabbed or shot. The reported victimization rates of MTO families are about four times higher than those computed from a recent national survey of public housing households in family developments reported in Zelon et al.(1994). ${ }^{15}$

\footnotetext{
15 Note that the victimization rates may be somewhat exaggerated in the Baseline Survey. Despite explicit instructions that the survey was being conducted by outside researchers and that the housing authority would not receive copies of individual responses, our fieldwork revealed that some respondents assumed their answers could influence their acceptance into the program. This may have encouraged them to over-report criminal victimization. The high
} 
In comparison to other tenants in the same public housing development in which the MTO families lived, Goering et al. (1999) found that MTO and non-MTO households were very similar in household size and in number of children under 18. MTO households (pooling across all five sites) were more likely to be female-headed (93 percent vs. 78 percent), receiving AFDC ( 75 percent vs. 51 percent), not working ( 88 percent vs. 70 percent), and younger (median age 33 vs. 39 ).

For the 540 Boston households that are the focus of our analysis, the characteristics reported by the household head in the Baseline Survey are presented in Table 2. The majority of these families are headed by a single mother who receives public assistance. 27 percent of the household heads were employed (either part-time or full-time) at the time of the baseline survey, and 22 percent own an automobile. These patterns are not surprising given that eligibility for the program was restricted to families with children living in public housing (or project-based assisted housing) in high poverty, inner-city census tracts. While all families have children and most of these are younger children (58 percent of households have no teenagers and 30 percent of all children are less than age 6 at the time of random assignment), nearly all of the heads ( 94 percent) are at least 25 years of age.

Under random assignment to one of three groups in MTO, the Baseline Survey characteristics should be the same on average across the groups except for variation due to sampling. In computing the differences in means between the Control group and the two treatment groups, we find that two of the 48 differences had a p-value of less than .05, based on the 24 characteristics in Table 2 , which is quite consistent with random assignment. ${ }^{16}$ One additional factor when comparing groups is that the randomization proportions were changed after the first 450 households were randomly assigned; all statistics we report are therefore weighted to account for this change. ${ }^{17}$

victimization rates could also be caused by respondents telescoping events that occurred before the time frame of the questions into the six month period.

${ }^{16}$ The two characteristics that significantly differ are "if family size is 2 " which is 14 percentage points higher in the Section 8 Comparison group than in the Control group, and "if no family in neighborhood" which is 12 percentage points lower in the Experimental group than in the Control group. A test of the joint significance of the 48 differences has an F-statistic of 1.2, with a p-value of .21, also indicating no significant differences between the groups.

${ }^{17}$ For the computation of all descriptive statistics and econometric estimates in this paper, the data are weighted. For the earlier 450 sample households, the Exp:Sec8:Control random assignment ratio was 225:85:140. For the later 90 households, after March 1996, the ratio was 15:35:40. The randomization proportions were adjusted after it became apparent that more Experimental families and fewer Section 8 Comparison families were taking-up the offered subsidy than had been projected. We weight the data under these two randomization proportions to reflect the overall sample ratio of 240:120:180, or 4:2:3. For example, there are relatively fewer Control households in the earlier period 


\section{An Econometric Interpretation of the Estimated Effects}

A critical issue in the study of the impact of residential location on individual outcomes is the selection problem arising from the likely systematic sorting of individuals among neighborhoods on the basis of important (unobserved) determinants of socioeconomic outcomes. To identify the causal effect of residential location on an outcome of interest, we must compare people living in different locations who would have experienced the same outcome, at least on average, if they had lived in the same location. Since people cannot be located in two places at once, this comparison necessarily involves a counterfactual that cannot be directly observed.

In our analysis of the MTO program, we study safety, health, and other outcomes for families originally living in public housing who were offered a Section 8 subsidy to defray their rental payments in a privately owned apartment. We then compare the average outcomes of these treatment-group families to a Control group of families originally living in the same public housing projects, but who were not offered the subsidy. The key to this analysis is that the offer of the subsidy is randomly assigned by lottery. Thus, the Control group is used to identify the average outcomes corresponding to the counterfactual state that would have occurred for families in the treatment group if they had not been offered a rental subsidy through the lottery. These comparisons are commonly known as "Intent-To-Treat" (ITT) effects.

We illustrate our approach to estimation in a simple regression framework. Let D be an indicator variable for use of a Section 8 subsidy to move through the MTO program, or treatment take-up. Let Z (with coefficient $\pi$ ) be an indicator variable for being eligible for an MTO program subsidy, or treatment group assignment. Let $\eta$ be the other determinants of subsidy use, which is determined as in equation (1) with i indexing households.

$$
\text { (1) } \mathrm{D}_{\mathrm{i}}=\mathrm{Z}_{\mathrm{i}} \pi_{1}+\eta_{\mathrm{i}}
$$

The Intent-To-Treat effect (ITT) is captured by the ordinary least squares (OLS) estimate of the coefficient $\pi_{2}$ in a regression of the outcome $(\mathrm{Y})$ on an indicator for assignment $(\mathrm{Z})$ to a treatment or control group as in equation (2):

$$
\mathrm{Y}_{\mathrm{i}}=\mathrm{Z}_{\mathrm{i}} \pi_{2}+\varepsilon_{\mathrm{i}}
$$

than in the overall sample, so these observations are upweighted by $(180 / 540) /(140 / 450) \approx 1.07$. Thus, using the weights allow us to abstract from this change and address the counterfactual question of what our results would look like if the randomization probabilities had remained constant throughout our time period at the overall sample ratio. 
ITT is an average of the causal effects for those who take-up the treatment and those who do not.

The characteristics known prior to randomization $(\mathrm{X})$ should have the same distribution within the treatment and control groups because they are statistically independent of group assignment. Thus, including them in a regression like (2) will not change the coefficient $\pi_{2}$ (unless $\mathrm{X}$ happens to differ between groups due to the variability in a small sample). Xs may still be included to improve the precision of the treatment effect estimates, however, if they are related to $\mathrm{Y}$ and thereby reduce residual variation in the regression, as in equation (2').

(2') $\quad \mathrm{Y}_{\mathrm{i}}=\mathrm{Z}_{\mathrm{i}} \pi_{2},+\mathrm{X}_{\mathrm{i}} \beta_{2},+v_{\mathrm{i}}$

Under several assumptions (treatment group assignment is random; Control group members are prohibited from receiving program subsidy assistance; the effect on outcomes of treatment assignment works entirely through making a subsidized move through the program ${ }^{18}$ ), we can use treatment assignment as an instrumental variable to estimate the parameter commonly known as "the effect of Treatment on the Treated" (TOT). The TOT parameter measures the average effect of the treatment on those in the treatment group who actually receive the treatment (i.e., who actually move using a Section 8 rental subsidy provided by the MTO program). One estimate of TOT is $\pi_{2} / \pi_{1}$, or the ITT divided by the proportion receiving the treatment. ${ }^{19}$ Formally, we will use an alternative estimate, the parameter $\gamma$ from a two stage least squares (2SLS) regression of Y on D with Z used as an instrumental variable for $\mathrm{D}$, as in equation (3).

$$
Y_{i}=D_{i} \gamma+X_{i} \beta_{3}+v_{i}
$$

The 2SLS estimate of $\gamma$ in (3) is a regression-adjusted estimate of TOT, using the information in X to obtain additional statistical precision, and is asymptotically equivalent to the unadjusted indirect

\footnotetext{
${ }^{18}$ This assumption says that those who did not accept the treatment offer had no average treatment effect in comparison to those who would not have accepted the treatment if it had been offered to them. For the Experimental group, this assumption implies that the later outcomes of households who met with a housing mobility counselor were not affected by the counselor if that household did not make a subsidized move through the MTO program. For both treatment groups, this assumption implies that the experience of housing search induced by assignment to a treatment group did not affect later outcomes if that household did not make a subsidized program move. We believe that this assumption is probably not strictly true, but we also believe that effects of mobility counselors (who mainly provided housing advice and not general social services) and of housing search on outcomes such as child behavior, victimization, or health for those who did not make a subsidized move through the program are likely to be orders of magnitude smaller than the effects of moving to a new residential location.

${ }^{19}$ The use of this deflator based on the proportion in the treatment group who actually received the treatment was introduced in the program evaluation context by Bloom (1984); see Heckman, LaLonde, and Smith (1999) for a comprehensive discussion of alternative parameters of interest in the evaluation of social programs.
} 
least squares estimate of TOT, $\pi_{2} / \pi_{1}$.

There are two treatment groups in this application, so we will compute separate estimates for both the Experimental and Section 8 Comparison groups by making $\mathrm{D}$ and $\mathrm{Z}$ matrices of two indicator variables for these groups. In this research we will stack data for all three MTO groups and present regression-adjusted ITT and TOT estimates based, respectively, on OLS estimates of (2') and on 2SLS estimates of (3), using treatment group assignments as instrumental variables for Section 8 subsidy use through the program.

Conceptually, the Treatment-On-Treated effect is the estimated difference in outcomes between those who actually use the rental subsidy through the program and those in the Control group who would have used the subsidy if it had been offered to them. Among those assigned to a treatment group, we refer those who decide to take-up the offered subsidy as "compliers" and those who decide not to take-up the offered subsidy as "never takers," following a literature on treatment effect estimation (for example, see Angrist, Imbens and Rubin, 1996). ${ }^{20}$ Table 3 summarizes the relationship between compliers and never takers in the treatment and control groups. As before, let $\mathrm{Y}$ be an outcome, let $\mathrm{D}$ be an indicator of program subsidy use, and let $\mathrm{Z}$ be an indicator of treatment group assignment by lottery. Now, however, let $\mathrm{C}$ refer to potential compliance with the treatment. Potential compliance is observed in the treatment group $(\mathrm{C}=\mathrm{D}$ when $\mathrm{Z}=1)$, but not observed in the control group. Thus, "Control Compliers" $(\mathrm{C}=1, \mathrm{Z}=0)$ do not receive the treatment, but they would have accepted the treatment had it been offered to them. Similarly, "Control Never Takers" $(C=0, Z=0)$ would not have accepted the treatment if it had been offered to them.

Using this notation, we can more precisely define the Intent-To-Treat (ITT) and TreatmentOn-Treated effects (TOT).

ITT: $\quad \mathrm{E}[\mathrm{Y} \mid \mathrm{Z}=1]-\mathrm{E}[\mathrm{Y} \mid \mathrm{Z}=0]$

TOT: $\mathrm{E}[\mathrm{Y} \mid \mathrm{C}=1, \mathrm{Z}=1]-\mathrm{E}[\mathrm{Y} \mid \mathrm{C}=1, \mathrm{Z}=0]$

To assess the magnitude of the TOT effect in relative as well as absolute terms, it is useful to have a benchmark level of the outcome in the absence of treatment for comparison. For example, if the TOT estimates show that the treatment changes a binary outcome by ten percentage points, there was a larger relative change if the observed mean level of the outcome for the treated compliers was .10

\footnotetext{
${ }^{20}$ In the terminology of Angrist, Imbens and Rubin (1996), note that there are no "always takers" or "defiers" in this application because no one in the Control group is offered a subsidy through the MTO program.
} 
than if it was .40. Following this logic, we use the mean outcome for treated compliers and the TOT difference to impute the Control Complier Mean outcome (CCM).

$$
\begin{aligned}
\mathrm{CCM} & =\mathrm{E}[\mathrm{Y} \mid \mathrm{C}=1, \mathrm{Z}=0] \\
& =\mathrm{E}[\mathrm{Y} \mid \mathrm{C}=1, \mathrm{Z}=1]-\{\mathrm{E}[\mathrm{Y} \mid \mathrm{C}=1, \mathrm{Z}=1]-\mathrm{E}[\mathrm{Y} \mid \mathrm{C}=1, \mathrm{Z}=0]\} \\
& =\mathrm{E}[\mathrm{Y} \mid \mathrm{C}=1, \mathrm{Z}=1]-\mathrm{TOT}
\end{aligned}
$$

Although $\mathrm{E}[\mathrm{Y} \mid \mathrm{C}=1, \mathrm{Z}=0]$ is not directly observable, $\mathrm{E}[\mathrm{Y} \mid \mathrm{C}=1, \mathrm{Z}=1]$ and TOT can be estimated. With a mean outcome for treated compliers of .40 and a TOT effect of .10, for example, the mean outcome level among the "Control Compliers" who would have taken-up a subsidy had it been offered to them would be .30 , and the change in the outcome for compliers relative to the level of the outcome in the absence of the treatment would be 33 percent.

Another important issue in interpreting our MTO results is their external validity. Our results have direct bearing on similar expansions of rental subsidies of moderate scale in Boston or in other cities, and are most applicable to forecasting outcomes for situations in which families are offered a rental subsidy but allowed the alternative of remaining in their original location. Our analysis focuses on families who are caused to move into neighborhoods where there tend to be few families receiving public rental assistance. There may well be additional effects not captured in our analysis if the subsidized movers were to become a large enough presence to affect aggregate neighborhood characteristics. $^{21}$

Finally, it is worth emphasizing that our current study is about the early impact of MTO on Boston families. There are many reasons to expect that the initial outcomes will differ from the final outcomes. For example, a move from a distressed environment could improve mental health in the long run, but initially increase the probability that a household head is depressed if the move cuts the head off from her previous social networks. Similarly, children could initially have trouble adjusting to new schools, but eventually have fewer behavior problems and perform better in school because of exposure to peers with greater expectations of graduating from high school. Indeed, even if MTO had no beneficial impact on the adults in its households, the program could still be extremely valuable if it led to positive child outcomes. Many important outcomes for children in MTO families will not be apparent for years.

\footnotetext{
${ }^{21}$ This type of feedback is also referred to as "general equilibrium" effects (Heckman 1999).
} 


\section{Mobility and Neighborhood Characteristics}

As intended, the MTO program had a substantial impact on the residential location of households offered subsidies to live in a private market apartment. The share of families who used a program subsidy to move from their original location (which we refer to as the "take-up rate") was .48 for the Experimental group and .62 for the Section 8 Comparison group, as reported in Panel A of Table 4. For those using a program subsidy, these families were free to move again after one year while continuing to receive the rent subsidy. In particular the Experimental group was no longer restricted by the poverty rate of the Census tract in choosing their location. In analysis of the locations of households at the time of the Follow-up Survey in the second row of Panel A, we find overall that few Control (.05) and Section 8 Comparison (.12) households were living outside the city of Boston, while the Experimental group (.28) households were much more likely to reside in outside the city limits. ${ }^{22}$ During the 1-3.5 years that elapsed by the time of the Follow-up Survey, a substantial share (.27) of Control households had moved out of the housing project or other Census block group in which they were living at the time of the Baseline Survey. Among the Experimental group, 60 percent of households had moved out of their original location (48 percent through MTO and 12 percent independently). Among the Section 8 Comparison group, 68 percent had moved (62 percent through MTO and 6 percent independently).

To assess the differences in residential locations of program participants, we present the mean characteristics of local residents based on 1990 Census tract data. Panel B of Table 4 shows that the local areas in which Experimental and Section 8 Comparison households were living at the time of the Follow-up Survey were significantly different on average from the Control households across many different dimensions, including lower poverty rate, lower welfare receipt, lower prevalence of female-headed households, higher proportion of managerial and professional workers, and higher education levels. ${ }^{23}$ The Section 8 Comparison group had smaller differences relative to the control

\footnotetext{
${ }^{22}$ Nearly all of those outside the city limits were living in Boston's surrounding communities, although there were six Experimental and two Control households who moved out to other states. In addition, there were three Section 8 Comparison households living in Puerto Rico with whom we completed interviews but from whom were unable to obtain street addresses that could be matched to Census tracts; these household are therefore not included in Table 4.

${ }^{23}$ At the time of the Follow-Up Survey, the two treatment groups also lived in census tracts with a much higher share of full-time/full-year workers and a larger proportion of owner-occupied housing units than the Control group. We have also replicated these analyses of neighborhood characteristics with Census block group data, and the results are quite similar. The mean poverty rates for block groups are as follows: Exp .250; Sec8 .275; and Control .388.
} 
group in racial composition and fraction speaking almost no English.

Panel C provides information about the peers children are exposed to in school. Specifically, it provides average reading and math test score percentiles for the schools that MTO children were attending at the time of the Follow-up Survey. These percentiles are calculated by taking the average test score for the students in the school from a statewide test and then determining the fraction of Massachusetts students who attend schools with average test scores below the average score for students in the school that the MTO child attends. ${ }^{24}$ The Control group children attend schools that on average have reading test scores in the eighth percentile and math test scores in the tenth percentile of the school test score distribution. The Experimental group experienced an eight percentile point increase in school average reading scores, and a six percentile point increase in average math scores. The results for both reading and math test scores indicate that even though many families are moving through MTO to neighborhoods with substantially less poverty than their origin neighborhoods, over 85 percent children in Experimental households that made program moves still attend schools with average test scores below the state median. The Section 8 group experienced smaller and statistically insignificant increases in school quality as measured by test scores. The small changes for the Section 8 group are not surprising since many of the households remain in the city of Boston with many of their children staying in their original schools.

The fact that the average neighborhoods of the Experimental and Section 8 Comparison groups are similar on many dimensions does not convey the differences in the distribution of tract characteristics. Data on the distribution of tract poverty rates is presented for the three MTO groups in columns 1-3 of Table 5. Members of Section 8 Comparison group were the least likely to be in a tract with a poverty rate of greater than 40 percent because of their higher subsidy take-up rate.

Columns 3-5 show the distribution by Census tract poverty rate for households who did not make a subsidized move through the MTO program. The mean poverty rates for the three groups are within one percentage point of each other and the distributions are quite similar. This implies that

\footnotetext{
${ }^{24}$ The test scores come from the 1996 Massachusetts Educational Assessment Program (MEAP). The test was administered to students in grades 4,8 , and 10 . For schools that contained two tested grades, we counted the grade closest to the grade of the MTO child. Our sample size for these estimates is 408 compared with 488 for most child outcomes. The smaller sample size occurred because in some cases we were not able to match the school name that was provided to us by the MTO parent to our list of all schools in Massachusetts. The MEAP was not administered to students in private schools or charter schools. We did not find any noticeable differences in the fraction of students attending private or charter schools across the three groups so we do not believe that this attrition is biasing our results.
} 
the mean poverty rates are essentially the same within the Control group for those who would have taken a program rent subsidy if offered (Control Compliers) and those who would not have taken it (Control Never Takers). ${ }^{25}$ In other words, those in the Control group who would have utilized the rent subsidy if offered were no more likely move to a lower poverty neighborhood on their own in the absence of a subsidy than those who would not have utilized the subsidy.

The Census tract poverty rate distribution for households who did make a subsidized move through the MTO program, the Treatment Compliers, is shown in columns 6-7 of Table 5. Nearly all of the Experimental households initially moved to a Census tract with a poverty rate of less than 10 percent as prescribed by program rules, but by the time of the Follow-up Survey (1-3.5 years after random assignment) 74 percent were living in tracts with less than a ten percent poverty rate because some had made subsequent moves to higher poverty tracts. Among Section 8 Comparison group members who moved through the MTO program, only 18 percent were living in a tract with a poverty rate less than ten percent. In analyses not shown in Table 5, we find that among those in both groups who initially made a subsidized move outside the Boston city limits, 14 percent had returned to live within Boston at the time of the Follow-up Survey. But for both groups of movers, there were no families living in a tract with a poverty rate of greater than forty percent, in comparison to an overall share of 60 percent in columns 3-5 among those who did not make a subsidized move. In summary, about three quarters of the Experimental Compliers moved and remained in neighborhoods with low poverty rates (less than 10 percent), while three quarters of Section 8 Comparison Compliers moved to neighborhoods with more moderate poverty rates (10-30 percent).

\section{Child Health and Behavior Problems}

Although the previous section documents that the residential surroundings of those who moved through the MTO program differ on many dimensions, the dimension most salient to participating families was fear that their children would be exposed to violence. In the course of our qualitative fieldwork, we developed a hypothesis that the fear and anxiety of living in a violent

\footnotetext{
${ }^{25}$ As discussed in Section III, the Overall Control mean is a weighted average of the Control Complier mean and the Control Never Taker mean: $\mathrm{E}[\mathrm{Y} \mid \mathrm{Z}=0]=\mathrm{E}[\mathrm{Y} \mid \mathrm{C}=1, \mathrm{Z}=0] \operatorname{Pr}[\mathrm{C}=1, \mathrm{Z}=0]+\mathrm{E}[\mathrm{Y} \mid \mathrm{C}=0, \mathrm{Z}=0](1-\operatorname{Pr}[\mathrm{C}=1, \mathrm{Z}=0])$. Under the identifying assumptions in section III, the difference between the Control Complier mean and the Control Never Taker mean is equivalent to: $(E[Y \mid Z=0]-E[Y \mid D=0, Z=1]) / \operatorname{Pr}[\mathrm{D}=1, \mathrm{Z}=1]$. Throughout this paper, we estimate the statistical significance of this difference without covariates for simplicity.
} 
neighborhood may cause emotional and behavioral problems that may adversely affect the mental health of children. This hypothesis is encapsulated in the comments of one woman who described to us why she had used an MTO subsidy to move to a suburban location.

As long as the kids is safe, that what my main concern was. ... They can't grow up normally in an atmosphere of fear. They can't play games and stuff. So I had to do it. And that was the best chance when they said we had to move in the suburbs. Living in the same area, that's not good. Even the elderly people, they living in fear, captive in their own homes. My mother lives like that. It's terrible. ... In the 'hood -- my kids, they had friends. But I wouldn't let them go out, because I was afraid. Bullets don't got no name.

This same woman described to us a visit she took to her old neighborhood with her four year old daughter: "Even now, we can't drive up the street. My baby, she so scared that she start cryin'. 'Nono-no.' She don't even want to go near there. It's amazing how little kids remember that stuff."

Our fieldwork was supplemented by the medical literature that documents an association in clinical settings between chronic exposure to violence and distinctive patterns of behavior, such as difficulty concentrating because of fatigue due to sleep disturbances or images of traumatic events, fearfulness of being alone, and aggressiveness due to behavior imitation or self-protection (Augustyn et al. 1995, Groves et al. 1993). To assess the impact of residential location on the mental health of children, we asked household heads in the Follow-up Survey if their children had exhibited various behavior problems during the past three months.

To provide some context about the prevalence of behavior problems among MTO children prior to participation in the program, we report in Table 6 Baseline Survey statistics from a number of questions asked about each child regarding learning and behavior issues.. The overall shares by sex are reported for children ages 6-15. The share of boys who had at least one of the learning or behavioral problems in rows 1-6 of Table 6 was .40, while the share of girls was .24. Regarding positive learning experiences, the shares for boys and for girls of doing advanced work in school in row 7 were both .14 and .11, respectively.

The questions we chose to administer in the Follow-up Survey focused more directly on particular types of behaviors that the mothers could observe, as opposed to questions generically about behavior problems or questions requiring intuition about how their child was feeling. Using items fielded previously by in the National Health Interview Survey and the National Longitudinal 
Survey of Youth Children's Supplement, we selected a subset of seven questions regarding: trouble getting along with teachers, disobedience at home, disobedience at school, hanging around with troublemakers, bullying others, inability to sit still, or depression. To summarize the responses to the seven behavior problem questions, we also created an index that is the fraction of the problems that were "sometimes" or "often" true of the child, as opposed to "not true."

We present results on behavior problems in Table 7 separately for boys and girls because they turn out to be strikingly different. Since we use the same table structure for a variety of outcomes, we explain it here in some detail.

Each row of Table 7 corresponds to a different outcome from the Follow-up Survey. In the first row, the outcome is the household head's report of the proportion of behavior problems that her male child has. We find that the fraction of the seven behavior problems in the Control group was .33, as reported in row 1 of Table 7. In comparison, the Experimental group had a fraction of behavior problems 9 percentage points lower than the Control group, based on the Intent-To-Treat (ITT) estimates reported in column 2. Assuming that only those who made a subsidized move through the MTO program had a non-zero average treatment effect, the Treatment-On-Treated (TOT) effect for the Experimental group was an 18 percentage point reduction in behavior problems, reported in column 3. Then, since we can directly observe the responses of Experimental group members who did make an MTO subsidized move (Treatment Compliers), we compute the unconditional mean of their outcome. The implied average level of the outcome for those in the Control group who would have used an MTO subsidy if it had been offered to them (Control Compliers) is then the difference between the observed Treatment Complier mean and the estimated TOT effect, as discussed in Section III. We call this the Control Complier mean and report it in column 4. The Experimental group compliers experienced a change in behavior problems of -.18 from a mean .44 , a relative decrease of 42 percent.

Both the ITT and TOT estimates are regression adjusted, controlling for the Baseline Survey variables summarized in Table 2 (age, race, sex, marital status, family structure, disability, welfare receipt, education, employment, car ownership, mobility history, social contact, victimization, and neighborhood poverty rate) and Table 6 (child learning and behavior issues). These regressions adjust for differences in Baseline Survey characteristics that may have occurred by chance, and absorb residual variation to improve the efficiency of estimation. Because of the random 
assignment, the Baseline Survey Characteristics are essentially orthogonal to the treatment indicators, so the magnitudes of the point estimates do not change substantively when we include of covariates. For example, the simple difference in means of the Experimental and Control groups in behavior problems for boys is -.098, versus the regression adjusted ITT estimate of -.090.

Among girls in row 2, the ITT estimates show a reduction of less than five percentage points for both treatment groups, and the estimates are not statistically distinguishable from zero. Notably, this concentration of the effects in reduction of behavior problems among boys and not girls was also found in the recent evaluation of the New Hope employment assistance demonstration in Milwaukee (Bos et al. 1999). Also notable is the fact that the large treatment effects among boys reduce behavior problems (boys Exp Complier mean: .25; boys Sec8 Complier mean: .29) to a level which is still higher than that for girls in the Control group (girls overall Control mean: .19).

The generally high level of behavior problems among Control Complier boys suggests that households who had boys with behavior problems were more likely to accept an MTO program subsidy if one was offered to them. This hypothesis is supported by results showing that Households with a boy in a gifted and talented class were significantly less likely to take-up, and households with a boy with behavior problems were more likely to take-up and accept an offered subsidy. ${ }^{26}$ In contrast, behavior problems for girls in the Baseline Survey are associated with lower take-up.

Although analysis of the fraction of behavior problems allows us to aggregate information (facilitating the recognition of smaller effects common across indicators of particular behavior problems), the pattern of very high levels of behavior problems among boys in Control Complier households and large treatment effects is also evident when looking at some specific problems in analyses not shown in the table. For "cruel or mean to others," the average prevalence among complier boys implies a relative decrease of 83 percent in the Experimental analysis, and 69 percent in the Section 8 Comparison analysis. For "unhappy, sad, or depressed," only the Section 8 Comparison results are statistically significant, with a relative decrease of 69 percent among compliers. Again, the effects for girls are smaller percentage point differences (although sometimes

\footnotetext{
26 The seven indicators of behavior issues for boys from the Baseline Survey are marginally significant predictors of take-up among the Experimental and Section 8 Comparison groups. Pooling the Experimental and Section 8 Comparison groups, the joint F-test on behavior issues for boys has a p-value of .10, conditional on age. The p-value for girls is .29.
} 
similar in relative terms) and statistically insignificant. ${ }^{27}$

One mechanism through which these gender differences may be occurring is social contact with other children. Girls in Control Complier households were particularly likely to have had at least one friend in the neighborhood, but girls in Complier households from both treatment groups each had a significant relative decline of about 30 percent in their chance of having a friend in the neighborhood. We speculate that these socialization difficulties for girls may offset some of the benefits for mental health of living in a different neighborhood.

Regarding physical health, our fieldwork reinforced the idea that there were other important types of danger associated living in a public housing project. We were told about incidents in which children had been cut by broken glass littered in the courtyard. One woman described how the park at which they played in the projects was built on cement. "The place was not safe for the children to play. They had swings on concrete. Everything was on concrete. And that's where most of the accidents happened." A couple of times her daughter fell off the swing and hit her head -- once she was hurt seriously enough to be taken to the emergency room. (Eventually, they decided to stop playing in the park because shooting began to take place there.)

A substantial medical literature shows that living in the inner-city is associated with detrimental child health outcomes. Urban children have higher rates of accidents, injuries (Quinlan 1996), and asthma (Weiss et al. 1992). ${ }^{28}$

In the Follow-up Survey, we asked specifically about any injuries, accidents, or poisonings that a child may have been involved in during the past six months. Most injuries were related to a dangerous environmental factor (such as a used needle), were falls during "horsing around" and other play among children, or were sports-related (cycling, skating, ball-playing). In row 5 of Table 7 we report results for injuries and accidents. There was a relative decrease among Experimental Compliers of 74 percent from a Control Complier mean of .160. The effect for the Section 8 Comparison group was about half as large and not statistically significant. For a comparison, we

\footnotetext{
${ }^{27}$ For analysis of binary outcomes throughout this paper, we use linear probability models (LPM) for simplicity in computing 2SLS estimates, and correct the standard errors for heteroscedasticity. In general our results do not appear to be sensitive to whether we use LPM or probit estimates.

${ }^{28}$ In designing our MTO-Boston Follow-up Survey, our fieldwork was helpful in identifying appropriate outcomes on which to focus. For example, rates of lead exposure are high in urban apartments (Lanphear et al. 1996), but the program regulations requiring an inspection for lead prior to approval for a rent subsidy minimized this problem.
} 
estimated the six month prevalence of injuries, accidents, and poisonings in a national sample that we weighted to be demographically similar to MTO children. Our estimate of .029 is lower than all of the MTO groups including the Experimental Compliers. ${ }^{29}$

Asthma attacks are thought to be triggered in part by environmental factors, including crowding (Weitzman et al. 1992), poor air quality (Thurston 1997), stress (Wright 1998), and exposure to allergens from cockroaches, dust mites, mice, and rats and lack of heat (Gelber et al. 1993, Sharfstein et al. 1998). Stress could come from the exposure to violence we discuss in the next section, and many of the environmental irritants could result from poor housing. In the Baseline Survey, for instance, we found that 32 percent of MTO families reported that rats and mice were "a big problem", and 9 percent reported that the heating system was a big problem. Our field work suggested that a move out of a housing project apartment might remove a child from many of these environmental irritants. In row 6 of Table 7, we report a relative decline of 65 percent in the probability of an asthma attack requiring medical attention among Experimental Compliers (TOT p-value .083), from a Control Complier mean of .16. ${ }^{30}$ There was essentially no effect for the Section 8 Comparison group.

An obvious concern regarding the injury and asthma results is the qualification that the events were defined to "require medical attention." We had included this qualification for comparability to national surveys, and to have a clear definition of how serious an injury or asthma attack was in order to be counted in the data. However, medical care may have been less accessible in the locations to which the Experimental Compliers moved. We attempted to measure this accessibility by asking whether the child had been to the doctor for a regular checkup. In row 7 of Table 7 we

\footnotetext{
${ }^{29}$ The estimate of .029 is based on the 1988 National Health Interview Survey Child Supplement (NHIS-CS) data. Weights to adjust the national sample to reflect MTO demographics were based on indicators for age, sex, and gender of the child, and indicators for head of household having 12 years of education, or more than 12 years. These variables were used to predict the odds of participating in MTO versus being a national survey sample respondent, based on the exponentiated latent index of a logit model of participation estimated from stacked MTO and national survey data. Because the NHIS-CS uses a 12-month recall period instead of our 6 month recall period, we then deflate the NHIS-CH estimates for comparison to the MTO-Boston results. Our deflator of .68 (instead of a simple .50) is derived from research on NHIS-CH recall effects (Harel et al. 1994) and accounts for the fact the respondents appear to be less likely to report injuries if they occurred many months ago in the recall period.

${ }^{30}$ While we are not aware of comparable national data on asthma attacks, the NHIS-CH does show that only .08 of a sample demographically similar to MTO children report ever having had asthma. In contrast, the proportion of MTO children ages 6-15 in all three groups who are reported to currently have asthma is .22, which is consistent with previously cited research on the high incidence of asthma in poor urban areas.
} 
find that the Section 8 Comparison group actually had a larger point estimate reduction in regular doctors' visits than the Experimental group, although both effects are statistically insignificant. Based on this evidence, if access to medical care was the sole mechanism driving changes in reported injuries and asthma attacks, we would have expected any access-driven effects to have been at least as large in the Section 8 Comparison group as in the Experimental group. Another way to assess changes in access using the checkup variable is to directly infer that access to medical care as measured by checkouts only declined by 9 percentage points among Experimental Compliers, which suggests to us that access is unlikely to fully explain the relative decline in injuries of 74 percent and the decline in asthma attacks of 65 percent.

\section{Safety}

At the time of the baseline survey, 55 percent of household heads in our Boston sample reported that the main reason they wanted to move was "to get away from drugs and gangs." In one interview, for example, we began by asking a woman a general question about how she had found out about the MTO program.

The first time I heard about this program, it said Boston Housing. But I already had lived in Boston Housing before. It had got so bad with the crime scene, you know. Every time I looked out my window, there was dead bodies. So I didn't want my kids to grow up in that atmosphere.

In her first sentence, she began to tell us that she had initially thought MTO was a program for families who wanted to move into the projects. But after bringing up "Boston Housing," she began to immediately tell us the most important thing about public housing was the association with crime. In addition to concerns about developmental consequences as discussed in Section V, household heads were also afraid that their children would be physically harmed or even murdered. In this section we systematically assess these risks of safety and criminal victimization.

The previous section documents a strong impact of the MTO program in reducing behavior problems for boys. One hypothesis for this finding is that the anxiety caused by living in an unsafe neighborhood was an important cause of behavior problems. Although we cannot directly distinguish the safety channel from the effects of other environmental changes experienced by those who moved through the MTO program (such as changes in schools and peer groups), we can explore the salience and magnitude of changes in safety caused by MTO. We examined three types of self- 
reported measures of safety. First, we use the proportion directly reporting that they feel unsafe. Second, we asked about the frequency of three specific types of observable events (gunfire, drug dealing, and carrying of weapons) that our qualitative interviews suggested were important determinants of perceived safety. Third, we asked about victimization incidents.

In the Baseline Survey, MTO household heads were asked: "How safe are the streets near your home during the day?" About half (53 percent) reported that they felt "unsafe" or "very unsafe." In the Follow-up Survey during 1997-98 (1-3 years later), 39 percent of the Control group felt "unsafe" or "very unsafe" as reported in row 1 of Table 8. This improvement in safety over time could be the result of the 27 percent of control group households that moved between random assignment and the Follow-up Survey, or it could be the result of improvements in policing and safety that appear to have occurred in Boston Housing Projects over this period. The Experimental group compliers experienced a change in the prevalence of unsafe streets compared with the control group of -.31 from a mean .40 , a relative decrease of 76 percent. The analogous results are reported in columns 5-7 for the Section 8 Comparison group, whose members also reported a lower prevalence of feeling unsafe -- but this difference is not statistically distinguishable from zero.

The second row of Table 8 presents results on presence of drugs in the neighborhood. In the Baseline Survey, household heads were asked "In your neighborhood, how bad of a problem are drug dealers or users?" 74 percent reported that drugs were "a big problem," as opposed to a "small problem" or "no problem at all." In an attempt to develop a more interpretable metric of the intensity of the drug problem, we asked in the Follow-up Survey how often family members had seen people using or selling illegal drugs in the neighborhood. We found that the share in the Control group was .36 that had observed this behavior once a week or more in the past six months. In the Experimental group, the prevalence was 20 percentage points lower. Those complying with the Experimental treatment observed almost no drug activity; the relative reduction among compliers was 95 percent. In the Section 8 Comparison group, the incidence was 13 percentage points lower, a relative reduction among compliers of 54 percent.

Although no baseline survey evidence was collected about gunfire, we found that 21 percent of the Control group had heard gunfire once a week or more in the past six months. In the Experimental group, the prevalence was 12 percentage points lower -- with 100 percent eradication of exposure to gunfire among compliers. In the Section 8 Comparison group, the incidence was 10 
percentage points lower, a relative reduction of 72 percent among compliers.

We also asked the household heads whether their children had seen anyone carrying a weapon (such as a gun or a knife). Ten percent of Controls reported that a child had seen someone with a weapon (where we asked about up to two randomly selected children between the ages of 6 and 15 for each family). There was almost no observation of weapons among Experimental compliers, resulting an estimated relative reduction of 87 percent among compliers. The point estimate for the Section 8 Comparison group was also negative, but statistically insignificant.

Overall, the Control Complier means are generally higher than the overall Control means for both groups, which is consistent with a decision process in which those who take-up an MTO subsidy were those who would have been living in a more unsafe neighborhood in the absence of an MTO subsidy offer. The correlation between reporting an unsafe neighborhood in the Baseline Survey and making a subsidized move is positive (although not statistically significant) among those offered a subsidy which is also consistent with a process where neighborhood safety would have been relatively higher among compliers if they had not been offered a program subsidy.

We asked MTO household heads in our Boston Follow-up Survey about victimization of themselves and their children during the past six months, 1-3.5 years after enrollment in the program. While we had a sharp hypothesis that the treatment groups would be in neighborhoods with fewer drugs and guns, we had competing hypotheses regarding victimization, since families moving into new neighborhoods may be particular targets of crime, especially among children who at least initially may get into more fights or be more likely to have items stolen. Our measures of victimization were modeled on the redesigned National Crime Victimization Survey (NCVS). ${ }^{31}$ Overall, one quarter of Control group households in the Follow-up Survey in the Control group

${ }^{31}$ For details on the NCVS redesign, see the Bureau of Justice Statistics (1994) overview. Our Follow-up Survey included selected NCVS cues about people, places and things intended to assist respondents in recalling events, such as theft (of a purse, wallet, or jewelry), assault (involving a neighbor, friend, relative, or someone at work or school), or attacks with a weapon (such as a frying pan, scissors, rock, bottle, knife, or gun). In another attempt to improve upon the Baseline Survey victimization measures, we asked specifically about the dates of incidents in order to exclude those occurring more than six months prior to the interview -- although we do not have the multiple interviews with the same respondent that the NCVS does, which would improve our ability to exclude old incidents.

Following the NCVS, we classified reported incidents into property and personal crimes. Our property crimes include household burglary and attempted entry, vandalism, and theft not directly from a person. Our personal crimes include physical attacks, threats of attack, and theft directly from a person. We further classified personal crimes as principally involving the household head, at least one child, or involving both -- where involvement was defined as being present at the incident and being the person threatened, robbed, or attacked. Since our information on children's victimization is obtained from the household head, we probably underestimates actual victimization of children. 
reported at least one crime during the previous six months, and 12 percent had a head or child who was physically assaulted or robbed. We suspect that lower actual exposure to criminal activity and differences in the surveys both contribute to the lower victimization rates in the Follow-up Survey than in the Baseline Survey. ${ }^{32}$

The results in rows 5-7 of Table 8 report the proportion of households with one or more incidents of crimes of various types. Thirteen percent of Control households were victims of personal crimes during the past six months is which at least one child was involved. Over two-thirds of these personal crimes among children involved direct contact with the offender, such as mugging, fighting, punching, kicking, spitting, shoving, throwing of rocks, or "getting jumped" by a gang. The remainder involved attempted assault or verbal threats of violence. Experimental households had a prevalence 6 percentage points lower than the Control group (p-value .06). Assuming that only those who received a program subsidy (Treatment Compliers) had a non-zero treatment effect, column 4 shows that the implied mean for Control Compliers is .13, and the relative reduction in the prevalence of personal crimes involving at least one child was 80 percent. The difference for the Section 8 comparison group is negative and insignificant.

Seven percent of Control group household heads experienced personal crimes. Heads in the Section 8 Comparison groups have a lower prevalence of any personal crimes in the past six months, but the proportion is insignificantly different from the level in the Control group. The difference for the Experimental group is essentially zero.

Of the households with property crime incidents, 43 percent had thefts (e.g., of a bicycle on the porch), while the remainder had burglaries (e.g., VCR stolen) and attempted break-ins. For property crimes, both treatment groups show lower prevalence of any incidents within the past six months. The share of Control households with property crimes was 13 percent. The Experimental

\footnotetext{
${ }^{32}$ In Boston, fear of violent crime was a major influence in the daily lives of MTO families and a key motivator of mobility even though Boston families report the lowest criminal victimization in the Baseline Survey of any of the five MTO sites in Table 1. In the Baseline Survey, respondents were asked about break-ins, purse-snatching, threats with a weapon, assaults, stabbing/shootings affecting any householder. The proportion of households reporting at least one crime incident in the Baseline Survey was .37, and .18 report that they or someone who lives with them had been beaten, assaulted, stabbed, or shot within the past six months. In comparison, a 1994 telephone survey in public highrise family developments found that respondents or family members had experienced an assault or robbery in a .09 share of households (Zelon et al. 1994). Piehl et al. (1999) found that the 1997-98 period during the Boston Follow-up Survey to have had significantly lower youth homicide rates than during 1994-96. Additionally, Baseline Survey responses may be been influenced by a perception that reports of victimization might improve one's chances of a rent subsidy.
} 
households are 7 percentage points less likely to have had a property crime and the Section 8 Comparison households are 9 percentage points less likely. Among compliers, the relative decrease was 67 percent in the Experimental group and 65 percent in the Section 8 Comparison group. ${ }^{33}$

In sum, both the Experimental and Section 8 Comparison group household heads found their neighborhoods to be safer on most of our self-reported measures than the Controls, with the magnitude of the improvements and the statistical significance of the estimates generally somewhat larger for the Experimental group. These large changes suggest that increased safety could have been an important factor in reducing child behavior problems. Regardless of its impact on other outcomes, safety was clearly valued itself by participating families as a desirable outcome.

\section{Adult Health and Social Interactions}

In our qualitative interviews, one of the most striking contrasts we observed between adults who were living in public housing and those who had moved out of public housing was that current public housing tenants appeared to be in much more emotional distress. To take one example, a middle-aged Black woman who had lived in public housing for twenty-five years gave the following description of her experience:

When you go outside, you don't know what's flying around the corner. You gotta look both ways when you open the front door. You had to constantly look behind you to make sure nothing's comin' around you. ... It was like living in prison. I was afraid to get in my own car and go some place, and come back home and not know if your house would be shot out or what ...

After enrolling in MTO in 1994, she moved to a demographically older and more racially mixed part of Boston. "It's so beautiful. So nice. The neighbors are very friendly. ... I like the peace and quiet. I have peace of mind." Since there is a large literature on the impact of maternal mental health on parenting and child outcomes (Weissman et al.1984, Gelfand et al.1990), we speculate that this might be a mechanism by which the program could produce beneficial long-run results for the

33 In results not reported in the table, we analyzed the average number of incidents, as opposed to the proportion of households with any incident. The results for the average number of incidents are qualitatively similar to the results for the proportion with one or more incidents. There are fewer personal crimes involving children in the Experimental group, with a relative decline among compliers of 88 percent. Both the Experimental group (TOT p-value .065) and Section 8 Comparison group (TOT p-value .013) have more than two-thirds fewer property crimes among compliers. 
children as well as a direct effect on adults.

As a comprehensive measure of health, we report results in row 1 of Table 9 from a standard question on general health("In general would you say that your health is excellent, very good, good, fair, or poor?"). In the Control Group 58 percent of heads reported health that was good or better. The Experimental TOT effect is .24; the relative change from the Control Complier mean of .46 is a 52 percent increase in the share with health that was good or better. Similarly, the Section 8 Comparison TOT effect is .26; the relative change from the Control Complier mean of .52 is a 51 percent increase. The Control Complier Mean is significantly lower than the Control Never Taker mean in the Experimental group, suggesting that those with poorer health were more likely to accept the subsidy if offered - which may reflect the ability of the Experimental group counselors to facilitate the moves of those in poorer health.

To explore aspects of mental health, we asked two questions about calmness and happiness used to assess positive affect in the evaluation of the RAND Health Insurance Experiment. ${ }^{34}$ In the second row of Table 9, we find large treatment effects in reports of household heads feeling "calm and peaceful" during the past four weeks. ${ }^{35}$ The relative increase for Experimental Compliers was 58 percent from a Control Complier mean of .39, and the relative increase for Section 8 Comparison Compliers was 53 percent from a Control Complier mean of .43. The large increase is particularly notable for Experimental group members, since they are more likely to be in a neighborhood with few members of the same socioeconomic or racial/ethnic group as themselves, and this could increase social isolation and introduce countervailing distress. The relative changes for feeling "happy" were also positive, but smaller in magnitude and statistically insignificant.

To work with a clear definition of a mental health problem, we focused on symptoms of a particular psychiatric condition, major depressive episode (MDE), using a series of questions from

\footnotetext{
${ }^{34}$ For information on the development of these items, see Ware et al. (1994). For results from the RAND Health Insurance Experiment, see Manning et al. (1987).

${ }^{35}$ For context, we examined a sample from the 1987 National Medical Expenditure Survey (NMES) weighted to reflect the demographic composition of the MTO participants (using race, sex, age, and education), and found them more likely to be calm and peaceful a good bit of the time or more (.57) than the MTO Controls (.47). Experimental Compliers (.62) and Section 8 Comparison Compliers (.66) are more similar to the general population ages 18-64 (.66).
} 
the Composite Diagnostic Interview Short Form (CIDI-SF). ${ }^{36}$ Based on their work with the more comprehensive National Comorbidity Survey, Nelson et al. (1998) develop a rule for predicted MDE cases by assigning a probability to respondents with a particular number of symptoms. The MTO sample appears to have a much higher prevalence of MDE symptoms than a national population of similar age, race, education, and sex. ${ }^{37}$ In the 1997 Women's Employment Survey in Michigan (Danziger et al. 1999), however, a population of single mothers receiving cash assistance was found to have a predicted MDE of .27, within sampling error of the .25 mean for the MTO Control group. This suggests that the Control group may be fairly typical of very low-income single mothers, and that the high rate of MDE is not an exaggerated response to the interviewer in the hope that it will somehow improve their prospects for receiving subsidy assistance in the future. For the outcome of predicted MDE in Table 9, row 4, we find that the point estimates suggest a decline in depression among the treatment groups, but differences are statistically insignificant; we note that the estimated magnitude of the relative declines of 29 percent for Experimental Compliers and 43 percent for Section 8 Comparison Compliers are quite large, which implies that our sample size is simply not big enough to reliably detect changes of large magnitude for this outcome.

One potential consequence of moving to a new residential location may be that it is more difficult to maintain or to establish social contact with friends and relatives, which may be a mechanism that could adversely affect mental health. In order to assess any differences in social interactions caused by participation in the MTO program, we asked several questions in the Boston Follow-up Survey, and results are reported in rows 5-8 of Table 9. First, respondents were asked

\footnotetext{
${ }^{36}$ MDE is defined in the Diagnostic and Statistical Manual of Mental Disorders (DSM-IV) as having several particular symptoms within a two-week time period. The questions in the CIDI-SF were chosen for their correspondence with a more comprehensive battery of MDE questions from the National Comorbidity Survey (Kessler et al. 1994, 1998). In the sequence of MDE questions, respondents are asked whether they have been "sad, blue, or depressed" or have "lost interest in most things" for any two-week period within the past 12 months in which the symptoms lasted at least half the day for almost everyday or more during the two-week period. For respondents indicating either depression or loss of interest, they are then asked if they have the following additional symptoms during the two weeks: more tired out or low on energy, weight gain or loss of more than 10 pounds, trouble falling asleep nearly every night, more trouble concentrating than usual, feeling down on self/worthless/no good, or thinking about death. Also, anyone volunteering that they are taking prescribed medication for depression is classified as having the maximum number of symptoms.

${ }^{37}$ In tabulations from the CIDI-SF administered in the 1997 National Household Survey of Drug Abuse weighted to reflect the demographics of the MTO sample, the predicted MDE probability was .12 as opposed to .25 in the MTO Control group. In the general population of adults ages 18-64 with children, predicted MDE was .07.
} 
about the number of times they had visited in person with friends and family in the past month. The point estimates of the ITT effects suggest that Section 8 Comparison and Experimental families are less likely to have visits to their home and more likely to make visits to the homes of others, but all of these differences are statistically insignificant. To assess social isolation, we examined whether a respondent reported any visits in the past month, either to their own home or to the homes of friends or family. 90 percent of the households in all three groups had at least one visit, and there were essentially no differences between the groups. The two treatment groups also had a slightly higher proportion of household heads who have spoken on the telephone with close friends or relatives four times or more in the past week, but these differences were also insignificant. To provide some context on MTO participants in comparison to the general population, we also computed the frequency of social contacts from the 1987 NMES. ${ }^{38}$ Overall, our conclusion is that the contact with friends and relatives among the MTO participants is fairly similar to the general population and to a demographically similar national sample.

Two other measures of social interactions that we examined were attendance at religious services and social trust. 57 percent of Control group heads reported having been to a church or place of worship within the past 30 days. The point estimate of the ITT difference between the Experimental group and the Control group was essentially zero, and the difference between the Section 8 Comparison group was negative and statistically insignificant. The MTO sample appears to go to a place of worship monthly at about same rate as the general population of adults with children in the General Social Survey (GSS) from 1990-96 (.56 for all three MTO groups combined and for the GSS). Weighting the GSS by sex, age, race, and education, the prevalence was .49.

Our indicator of social trust is agreement with the statement "Most people can be trusted" as opposed to "You can't be too careful in dealing with people." Group average answers to this question have appear to be highly correlated with various aspects of social engagement, such as membership in civic organizations, voting, and spending time with neighbors (Putnam 1995). ${ }^{39}$ A

\footnotetext{
${ }^{38}$ These results show, for example, that among all heads of households with children (or spouses) ages 18-64, the proportion who spoke to close friends or relatives on the telephone "several days per week or more" in the past month was .57. Of the demographically weighted NMES respondents, the proportion was .51.

${ }^{39}$ Recent experimental work by Glaeser et al. (2000) suggests that this question predicts the trustworthiness of a person's own behavior, but not their trust in the expected behavior of others.
} 
share of only .08 of the Control group report that most people can be trusted. We find that the Experimental group exhibits more social trust than the Control group, with a TOT difference of .11 from a Control Complier Mean of .04, but the statistical significance of this TOT estimate is marginal (p-value .11). The difference between the Section 8 Comparison and Control groups is also positive, but the magnitude is smaller and statistically insignificant. In contrast to the previous indicators of social relations, the MTO sample differs substantially from the general population of adults with children, of whom 31 percent report that most people can be trusted in the GSS from 1990-96. This difference is largely due to demographic factors. Weighting the GSS by the sex, race, education, and age of the MTO sample, only 8 percent report that most people can be trusted.

\section{Economic Self-sufficiency}

A primary motivation for the MTO demonstration is to measure the impacts of residential neighborhoods on the welfare receipt and employment of low-income families. Many central cities have higher rates of joblessness and slower rates of job growth than their surrounding areas. This pattern suggests that providing low-income city residents with better access to jobs in the suburbs may improve their labor market outcomes. The MTO experimental treatment might be expected to reduce welfare use and increase employment by moving participants closer to suburban job centers. But moves to new suburban neighborhoods might disrupt pre-existing social networks that are an important source of labor market information and connections. It may take a significant amount of time in new neighborhoods to develop new networks. Thus, the theoretical predictions about the effects of MTO on welfare and employment are ambiguous. There are likely to be some disruptive in the short-run and some positive improvement in access to jobs over the longer run.

To the extent that families in the MTO experimental and Section 8 comparison groups are able to move to safer neighborhoods with more plentiful after-school activities for children, parents may have child supervision constraints relaxed and be freer to enter the labor market and to work longer hours. Indeed, Rosenbaum and Popkin's (1991) analysis of a survey of female household

heads in the Gautreaux program in Chicago found substantially higher employment rates (14 percentage points) for those who moved to the suburbs than for those who moved to other parts of 
the central city. ${ }^{40}$

Our primary source of information for assessing welfare and employment impacts in the Experimental and Section 8 Comparison groups are extracts from the Massachusetts Department of Revenue's Longitudinal Data Base. The data on monthly welfare (AFDC/TANF) receipt originated with the Massachusetts Department of Transitional Assistance. Quarterly earnings data is based on information from employer filings with the Massachusetts Department of Revenue. ${ }^{41}$ An advantage of these data sources in comparison to our survey is that we can construct a panel of quarterly observations from 92:1 (the first quarter of 1992) to $98: 3 .^{42}$ The most striking fact in this data is that rate of welfare receipt has fallen sharply, from 71 percent in 94:3 (prior to any random assignment) to 38 percent in 98:3. The employment rate, as measured by the fraction with positive earnings in a quarter, has also increased dramatically over time for all three MTO groups. Over four years, the employment rate rose from 29 percent in 94:3 to 48 percent in 98:3.

In Table 10, we show the results comparing MTO groups based on this data for our main sample of 540 household heads. In the first row, we pool data for the first four quarters after random assignment, and find that there are no significant differences between MTO groups in rates of welfare receipt. The results are essentially the same for later periods, 5-8 quarters and 9-10 quarters after random assignment. ${ }^{43}$ The results for employment similarly show no significant between-group differences. In results not shown in the table, we found no differences between MTO groups in quarterly earnings in constant 1999 dollars (including zeros for those with no reported earnings) for

\footnotetext{
${ }^{40}$ The differential survey response rates of $60 \%$ for the suburban movers and $88 \%$ among city movers are a source of concern in assessing this evidence, especially if the more successful suburban movers were more likely to have remained in their suburban location and been reached by and responded to the survey mailed to them.

${ }^{41}$ Note that these data from tax records included reports from all employers in the state, which is broader coverage than the Unemployment Insurance records often used in research. By definition, administrative records do not capture "off-the-books" or illegal earnings. However, some research has shown that the under-measurement appears to be symmetric across treatment and control groups in the national JTPA evaluation (Kornfeld and Bloom 1999), suggesting that differences between MTO groups may not be biased by this omission.

42 This was constructed by primarily by matching on Social Security Number (SSN). Names and birth dates were also used to find additional matches and validate the SSN matches; this refinement affected less than one percent of the quarterly observations.

${ }^{43}$ Measured in calendar time rather than time since random assignment, there is some modest evidence of a decline in welfare usage among treatment group members in 1998. Pooling all four 1998 quarters, the overall control mean is .425. The experimental group ITT estimate is -.025 (.031) and the Section 8 group ITT estimate is -.064(.034).
} 
these periods. Although these administrative data cover only earnings in the state of Massachusetts, we did confirm that over 95 percent of our sample was still living in Massachusetts in 1997 in the Follow-up Survey. Thus, even the most extreme assumptions about location and welfare or employment status of the remaining 5 percent would not generate significant differences in these between-group results.

We have also extended this analysis to the complete sample of all 961 household heads randomly assigned through MTO in Boston. Although these additional households were assigned later so that we can follow the complete sample for only seven quarters beyond random assignment, the results for welfare, employment and earnings are unchanged by this extension of the sample. In addition, our MTO-Boston Follow-up Survey asked about welfare receipt and a standard set of questions from the Current Population Survey on current labor market status (employment, unemployment, not in labor force), usual hours of work, usual weekly earnings, as well as some supplemental questions on fringe benefits. Again, we find no evidence of significant differences between groups on any of these dimensions.

The overall lack of impact is consistent with the finding reported in section II that only two percent of households in the Baseline Survey reported employment as one of the main reasons for wanting to participate in MTO. Also, analyses of the early labor market impacts of MTO using administrative data find no significant effects in employment during the first four years after randomization at the Baltimore sites (Ludwig, Duncan, and Pinkston, 2000), although their analysis

does suggest a decline in welfare receipt for the Experimental group. A household survey of early enrollees in the Los Angeles site finds no significant employment effects, but it does show modest evidence of increases in hours of work and weekly earnings for experimental and comparison group household heads relative to those in the control group (Hanratty, McLanahan, and Pettit, 1998).

\section{Conclusion}

This paper provides early estimates from an on-going investigation of the impacts of the MTO housing mobility demonstration on families originally residing in high-poverty housing projects in inner-city Boston. We find that approximately half (48 percent) of the households in the Experimental group (those randomly assigned to have access to rental assistance restricted to be used in a low-poverty area and provided with counseling assistance to help make such a move) have been 
able to use the program to move to a qualified neighborhood. Of those provided with a regular (geographically unrestricted) subsidy in the Section 8 Comparison group, 62 percent moved through the program. The Experimental treatment is more successful than regular Section 8 in relocating poor families into low-poverty and suburban neighborhoods. Regular Section 8 assistance is more effective in getting a larger share of families out of the most distressed communities.

Table 11 summarizes our main findings concerning the impacts of MTO on measures of family well-being and economic self-sufficiency (with outcomes defined such that negative changes correspond to improvements). Data from a baseline survey of program participants at all five MTO sites and extensive qualitative interviews with a small sample of participants in Boston indicate that fear of crime (drugs and gangs) and concerns about personal and family safety are the primary reasons motivating desires to move out of public housing in high-poverty, inner-city areas. The results of our MTO-Boston Follow-up Survey show large improvements in safety as measured by reductions in presence of gunfire and drugs, indicating that a major objective of the participants was achieved through the program. We also find that children in both the Experimental and Section 8 Comparison groups exhibit fewer behavior problems, and the Experimental group children have lower prevalence of injuries, asthma attacks, and personal crimes. The subsidized mobility opportunity has resulted in significant improvements in the general health status and mental health of household heads. But the changes in neighborhoods associated with mobility through MTO have not affected employment rates or earnings by a statistically detectable amount. Table 11 further illustrates that the magnitudes of the estimated relative changes in child health, safety, adult health outcomes among treatment compliers are very substantial.

We believe that one of the principal reasons that our results provide credible evidence of improvements in outcomes, particularly in the domain of health, is the consistent direction of the results for a variety of outcomes. Throughout this paper, we have considered each outcome separately, but in assessing the joint significance of the results it is of course important that all the outcomes are measured in the same sample, and also that both treatment groups use the same control group. What are the odds that all eight health outcomes in both treatment groups shown in Table 11 would indicate health improvements simply due to sampling variability? To compute these odds, we simulated the null hypothesis of no true difference between the Experimental, Section 8 Comparison, and Control groups, accounting for the covariance structure within households between 
outcomes. ${ }^{44}$ These results show that under the null of no difference, the odds were 617 to 1 of randomly obtaining 16 improvements in health outcomes for children and adults in the Experimental and Section 8 Comparison groups (p-value .00162). Thus, the consistency of the joint results appears to be extremely unlikely to be due to chance.

Although the eventual long-term effects of MTO on the children of participating families remains a crucial open research issue, the short-term impacts on adult and child circumstances are of substantial independent importance and may be harbingers of the long-run effects of changes in neighborhood environments. From the perspective of housing policy, our results clearly indicate that offering housing vouchers to the residents of distressed inner-city housing projects improves the well-being of those residents interested in moving out of public housing. More generally, the MTOBoston results strongly imply that neighborhoods have large impacts on the health and behaviors of children and adults from low-income families.

\footnotetext{
${ }^{44}$ Specifically, we drew 100,000 random samples with replacement of 520 households from the Control group in the MTO-Boston Follow-up Survey. These households were then randomly designated as treatment or control groups of the same sample sizes as the Experimental and Section 8 Comparison groups. For each sample, we then computed the between group differences and recorded the signs of the differences. Note that these are all of the health outcomes on which we collected data, so there is no issue of presenting only the significant outcomes.
} 


\section{References}

Aaronson, Daniel. "Using Sibling Data to Estimate the Impact of Neighborhoods on Children's Educational Outcomes." Journal of Human Resources 33:4 (1998): 915-946.

Abt Associates. "Characteristics of MTO Families." Unpublished tables from MTO Data System (March 1998).

Angrist, Joshua, Guido Imbens, and Donald Rubin. "Identification of Causal Effects Using Instrumental Variables." Journal of the American Statistical Association. 91 (June 1996): 444-455.

Augustyn, Marilyn et al. "Silent victims: Children Who Witness Violence." Contemporary Pediatrics (August 1995): 35-57.

Benabou, Roland. "Workings of a City: Location, Education, and Production." Quarterly Journal of Economics 108 (August 1993): 619-652.

Black, Sandra E. "Do Better Schools Matter? Parental Valuation of Elementary Education." Quarterly Journal of Economics 114 (May 1999): 577-99.

Bloom, Howard S. "Accounting for No-shows in Experimental Evaluation Designs," Evaluation Review 8:2 (1984): 225-246.

Bos, Hans et al. "New Hope for People with Low Incomes." Unpublished manuscript, Manpower Demonstration Research Corporation, April 1999.

Brooks-Gunn, Jeanne, Greg J. Duncan, Pamela K. Klebanov, and Naomi Sealand. "Do Neighborhoods Influence Child and Adolescent Development?" American Journal of Sociology 99 (September 1993): 353-95.

Bureau of Justice Statistics. Technical Background on the Redesigned National Crime Victimization Survey: NCJ-151172. Washington, DC: U.S. Department of Justice, 1994.

Coleman, James S. "Social Capital and the Creation of Human Capital." American Journal of Sociology 94 (1988): S95-S120.

Corcoran, Mary, Roger Gordon, Deborah Laren, and Gary Solon. “The Association Between Men's Economic Status and Their Family and Community Origins." Journal of Human Resources 27 (Fall 1992): 575-601.

Currie, Janet and Aaron Yelowitz. “Are Public Housing Projects Good for Kids?” Journal of Public Economics 75 (January 2000): 99-124.

Cutler, David M. and Edward L. Glaeser. "Are Ghettos Good or Bad?" Quarterly Journal of Economics 112 (August 1997): 827-72. 
Cutler, David M., Edward L. Glaeser, and Jacob Vigdor. "The Rise and Decline of the American Ghetto.” Journal of Political Economy 107 (June 1999): 455-506.

Danziger, Sandra et al. "Barriers to the Employment of Welfare Recipients." Unpublished manuscript, Poverty Research and Training Center, University of Michigan, April 1999.

Duncan, Greg J., James P. Connell, and Pamela K. Klebanov. "Conceptual and Methodological Issues in Estimating Causal Effects of Neighborhoods and Family Conditions on Individual Development." In J. Brooks-Gunn, G. Duncan, and J.L. Aber, eds., Neighborhood Poverty, volume 1. New York: Russell Sage Foundation, 1997, 219-50.

Epp, Gayle. "Emerging Strategies for Revitalizing Public Housing Communities," in David Varady, Wolfgang Preiser and Francis Russell, eds., New Directions in Urban Public Housing. Center for Urban Policy Research: Rutgers, NJ, 1998.

Feins, Judith D., et al. Moving to Opportunity for Fair Housing Demonstration: Program Operations Manual. (HUD-006483). Rockville, MD: HUD USER, July 1994.

Gelber, L.E. et al. (1993). "Sensitization and Exposure to Indoor Allergens as Risk Factors for Asthma Among Patients Presenting to Hospital," American Review of Respiratory Disease. 174: 573-578.

Gelfand, Donna M., et al. "The Effect of Maternal Depression on Children." Clinical Psychology Review, 10 (1990): 329-353.

Goering, John, Joan Kraft, Judith Feins, Debra McInnis, Mary Joel Holin, and Huda Elhassan. Moving to Opportunity for Fair Housing Demonstration Program: Current Status and Initial Findings. Washington, DC: U.S. Department of Housing and Urban Development, Sept. 1999.

Glaeser, Edward L., David I. Laibson, Jose A. Scheinkman, and Christine L. Soutter. "Measuring Trust." Quarterly Journal of Economics 115 (August 2000), forthcoming.

Groves, Betsy McCalister et al. "Silent Victims: Children who Witness Violence." Journal of the American Medical Association. 269:2 (1993): 262-264.

Hanratty, Maria, Sara McLanahan, and Becky Pettit. "The Impact of the Los Angeles Moving To Opportunity Program on Residential Mobility, Neighborhood Characteristics, and Early Child and Parent Outcomes.” Unpublished paper, Princeton University, April 1998.

Harel, Yossi, et al. "The Effects of Recall on Estimating Annual Nonfatal Injury Rates for Children and Adolescents." American Journal of Public Health. 84:4 (April 1994): 599-605.

Heckman, James J. "Accounting for Heterogeneity, Diversity and General Equilibrium in Evaluating Social Programs.” NBER Working Paper No. 7230, July 1999. 
Heckman, James J., Robert LaLonde, and Jeffrey Smith. "The Economics and Econometrics of Active Labor Market Policies." In O. Ashenfelter and D. Card, eds., Handbook of Labor Economics, vol. 3A. Amsterdam: North Holland, 1999.

Jargowsky, Paul A. "Take the Money and Run: Economic Segregation in U.S. Metropolitan Areas." American Sociological Review 61 (1996): 984-98.

Jargowsky, Paul A. Poverty and Place. New York: Russell Sage Foundation, 1997.

Jencks, Christopher and Susan E. Mayer. "The Social Consequences of Growing Up in a Poor Neighborhood." In L.E. Lynn Jr. and M.G.H. McGeary, eds., Inner-City Poverty in the United States. Washington, DC: National Academy Press, 1990, 111-186.

Kessler, Ronald C. et al. "Lifetime and 12 Month Prevalence of DSM-III-R Psychiatric Disorders in the United States." Archives of General Psychiatry. 51 (1994): 8-19.

Kessler, Ronald C. et al.. "The World Health Organization Composite International Diagnostic Interview Short-From." International Journal of Methods in Psychiatric Research, 7:4 (1998), 171185.

Kling, Jeffrey, Jeffrey Liebman, and Lawrence F. Katz. “Bullets Don't Got No Name: Consequences of Fear in the Ghetto." Unpublished paper, NBER, October 1996.

Kornfeld, Robert, and Howard S. Bloom. "Measuring Impacts on Earnings and Employment: Do Unemployment Insurance Wage Reports from Employers Agree with Surveys of Individuals?" Journal of Labor Economics, 17:1 (1999), 168-197.

Lanphear, B. P. et al. "Lead Contaminated House Dust and Urban Children's Blood Lead Levels." American Journal of Public Health. 86:10 (1996), 1416-1421.

Lucas, Robert E. “On the Mechanics of Economic Development." Journal of Monetary Economics 22 (February): 3-42.

Ludwig, Jens, Greg J. Duncan, and Paul Hirschfield, "Urban Poverty and Juvenile Crime: Evidence from a Randomized Housing-mobility Experiment." Quarterly Journal of Economics 116 (May 2001), forthcoming.

Manski, Charles F. "Identification of Endogenous Social Effects: The Reflection Problem." Review of Economic Studies 60 (1993): 531-542.

Manning, Willard et. al., "Health Insurance and the Demand for Medical Care: Evidence from a Randomized Experiment.” American Economic Review 77 (June 1987), 251-277.

Nelson, Christopher B. et al.. "Scoring the World Health Organization's Composite International Diagnostic Interview Short Form. Unpublished paper, World Health Organization, November 1998. 
Peroff, Kathleen A. et al. Gautreaux Housing Demonstration: An Evaluation of Its Impact on Participating Households. Washington, DC: U.S. Department of Housing and Urban Development, 1979.

Piehl, Anne M. et al. "Problem Solving and Youth Violence: An Evaluation of the Boston Gun Project." Unpublished manuscript, Kennedy School of Government, Harvard University, April 1999.

Putnam, Robert D. "Bowling Alone: America's Declining Social Capital." Journal of Democracy 6:1 (1995), 65-78.

Quigley, John M. "Housing Allowances and Demand-Oriented Housing Subsidies," in Roger Montgomery and Dale Rogers Marshall, eds., Housing Policies for the 1980s. Lexington MA: Heath and Company, 1980.

Quinlan, Kyran P. "Injury Control in Practice.” Archives of Pediatrics Adolescent Medicine. 150 (1996): 954-957.

Rosenstreich, David L. "The Role of Cockroach Allergy and Exposure to Cockroach Allergen in Causing Morbidity Among Inner-City Children with Asthma." New England Journal of Medicine. 336 (1997): 1356-63.

Rosenbaum, James E. "Changing the Geography of Opportunity by Expanding Residential Choice: Lessons from the Gautreaux Program." Housing Policy Debate 6 (1995): 231-269.

Rosenbaum, James E. and Susan Popkin. "Employment and Earnings of Low-Income Blacks Who Move to Middle-Class Suburbs." In C. Jencks and P. Peterson, eds., The Urban Underclass. Washington DC: Brookings, 1991.

Sarpong, Sampson B. "Socioeconomic Status and Race as Risk Factors for Cockroach Allergen Exposure and Sensitization in Children with Asthma." Journal of Allergy and Clinical Immunology. 97 (1996): 1393-1401.

Sharfstein, Joshua et al. Not Safe at Home. Boston: Boston Medical Center, 1998.

Thurston, George D. (1997). “Ozone, Particulate Matter Substantially Raise Asthma Morbidity And Mortality." Presentation to the ALA/ATS International Conference in San Francisco, May 17-21, 1997. Summarized at http://www.ama-assn.org/special/asthma/newsline/conferen/ozo521.htm

Von Hoffman, Alexander, "High Ambitions: The Past and Future of American Low-Income Housing Policy,” Housing Policy Debate 7:3. Washington, DC: Fannie Mae Foundation, 1996.

Ware, John E. Jr. et al. SF-36 Health Survey: Manual and Interpretation Guide. Boston: New England Medical Center, 1994. 
Weiss, KB et al. (1992). "Inner-city Asthma: The Epidemiology of an Emerging US Public Health Concern." Chest, 1992. 101s:362-367.

Weissman, M. et al. "Psychopathology of Children Ages 6-10 of Depressed and Normal Parents." Journal of the American Academy of Child Psychiatry. 23 (1984): 78-84.

Weitzman, M. et al. (1992). "Racial, Social, and Environmental Risk for Childhood Asthma." American Journal of Diseases of Children. 144: 1189-1194.

Wright, Rosalind J. (1998). "Review of Psychosocial Stress and Asthma: An Integrated Biopsychosocial Approach.” Thorax. 53: 1066-1074.

Zelon, Harvey et al. Survey of Public Housing Residents: Crime and Crime Prevention in Public Housing. Research Triangle Park, NC: Research Triangle Institute, 1994. 


\section{TABle 1 - MTO BASEline SURVEy DesCRIPTIVE Statistics OF HOUSEHOLDS IN 5 CITIES}

\begin{tabular}{lcccccc}
\hline \hline & Baltimore & Boston & Chicago & L.A. & $\begin{array}{c}\text { New } \\
\text { York }\end{array}$ & All \\
\hline If female household head & .98 & .92 & .95 & .83 & .93 & .92 \\
If Black & .97 & .38 & .98 & .55 & .53 & .66 \\
If Hispanic & .02 & .45 & .01 & .44 & .49 & .33 \\
Main reason to move: & & & & & & \\
$\quad$ Drugs, gangs & .56 & .58 & .52 & .64 & .51 & .56 \\
$\quad$ Better apartment & .28 & .30 & .21 & .12 & .29 & .25 \\
$\quad$ Better schools & .14 & .09 & .24 & .23 & .18 & .17 \\
In the past 6 months a & & & & & & \\
$\quad \begin{array}{l}\text { householder has been: } \\
\quad \text { Beaten or assaulted }\end{array}$ & .26 & .16 & .28 & .25 & .26 & .23 \\
$\quad$ Stabbed or shot & .11 & .07 & .11 & .11 & .12 & .11 \\
& & & & & & \\
Sample size & 630 & 792 & 603 & 511 & 736 & 3272 \\
\hline
\end{tabular}

Note: Source is Abt Associates (1998). Sample is randomly assigned MTO populations through June 1997 with available data as of March 1998. Percentage of data available from universe of random assignment: Baltimore 99\%; Boston 97\%; Chicago 85\%; Los Angeles 87\%; New York City 94\%; All sites 93\%. 


\section{TABLE 2 - MTO-BOSTON BASELINE SURVEY DESCRIPTIVE STATISTICS OF HOUSEHOLD CHARACTERISTICS}

\begin{tabular}{|c|c|c|}
\hline \multirow[t]{4}{*}{ Age as of 9/1/97 } & If head's age is $19-29$ & .30 \\
\hline & If head's age is $30-39$ & .46 \\
\hline & If head's age is $40-49$ & .18 \\
\hline & If head's age is $50+$ & .07 \\
\hline \multirow[t]{2}{*}{ Race } & If head is Hispanic & .45 \\
\hline & If head is Black and non-Hispanic & .37 \\
\hline Sex & If head is male & .09 \\
\hline Marital Status & If head has never been married & .59 \\
\hline \multirow[t]{5}{*}{ Family Structure } & If family size is 2 & .23 \\
\hline & If family size is 3 & .35 \\
\hline & If family size is 4 & .22 \\
\hline & If family size is $5+$ & .20 \\
\hline & If all household children are ages $0-12$ & .58 \\
\hline Disability & If any householder is disabled & .14 \\
\hline Welfare Receipt & If head is currently receiving AFDC/TANF & .64 \\
\hline \multirow[t]{3}{*}{ Education } & If head is currently enrolled in school & .17 \\
\hline & If head is high school graduate & .43 \\
\hline & If head is GED recipient & .24 \\
\hline Employment & If head's main activity is employment & .27 \\
\hline Car ownership & If head has a car that runs & .22 \\
\hline Mobility History & If head has moved $3+$ times in past 5 years & .10 \\
\hline \multirow[t]{2}{*}{ Social Contact } & If head has no friends in neighborhood & .42 \\
\hline & If head has no family in neighborhood & .69 \\
\hline Victimization & $\begin{array}{l}\text { If any householder was robbed, assaulted, or } \\
\text { threatened with a weapon within past } 6 \text { months }\end{array}$ & .29 \\
\hline \multirow{2}{*}{$\begin{array}{l}\text { Census Tract } \\
\text { Poverty Rate }\end{array}$} & If census tract poverty rate is less than $40 \%$ & .20 \\
\hline & If census tract poverty rate is greater than $43 \%$ & .32 \\
\hline
\end{tabular}

Note: Means are weighted, as discussed in Section II. Missing Baseline Survey data are imputed to the mean of nonmissing observations. Sample size is 540 households. 
TABlE 3 - DEFINITIONS OF COMPLIERS AND NEVER TAKERS

\begin{tabular}{|c|c|c|c|}
\hline & All & Complier $(\mathrm{C}=1)$ & Never Taker $(\mathrm{C}=0)$ \\
\hline $\begin{array}{l}\text { Offered } \\
\text { Treatment } \\
(\mathrm{Z}=1)\end{array}$ & $\begin{array}{l}\text { "Treatment Group" } \\
\text { E }[Y \mid Z=1] \\
\text { Sample mean observed. } \\
\text { In MTO, offered a subsidy } \\
\text { in the lottery. }\end{array}$ & $\begin{array}{l}\text { "Treatment Compliers" } \\
\mathrm{E}[\mathrm{Y} \mid \mathrm{C}=1, \mathrm{Z}=1] \\
\text { Sample mean observed. } \\
\text { In MTO, offered a subsidy } \\
\text { and used it to move } \\
\text { through program. }\end{array}$ & $\begin{array}{l}\text { "Treatment Never Takers" } \\
\mathrm{E}[\mathrm{Y} \mid \mathrm{C}=0, \mathrm{Z}=1] \\
\text { Sample mean observed. } \\
\text { In MTO, offered a subsidy, } \\
\text { but did not use it to move } \\
\text { through program. }\end{array}$ \\
\hline $\begin{array}{l}\text { Not Offered } \\
\text { Treatment } \\
(\mathrm{Z}=0)\end{array}$ & $\begin{array}{l}\text { "Control Group" } \\
\text { E[Y|Z=0] } \\
\text { Sample mean observed. } \\
\text { In MTO, not offered a } \\
\text { subsidy in the lottery. }\end{array}$ & $\begin{array}{l}\text { "Control Compliers" } \\
\mathrm{E}[\mathrm{Y} \mid \mathrm{C}=1, \mathrm{Z}=0] \\
\text { Sample mean not observed. } \\
\text { In MTO, not offered a } \\
\text { subsidy-but would have } \\
\text { used it to move through } \\
\text { program if offered. }\end{array}$ & $\begin{array}{l}\text { "Control Never Takers" } \\
\text { E[Y|C=0,Z=0] } \\
\text { Sample mean not observed. } \\
\text { In MTO, not offered a } \\
\text { subsidy-and would not } \\
\text { have used it to move } \\
\text { through program if } \\
\text { offered. }\end{array}$ \\
\hline
\end{tabular}




\section{TABle 4 - MobILITY AND CEnsus TRACT CHARACTERISTICS FROM MTO-BOSTON FOLLOW-UP SURVEY}

\begin{tabular}{|c|c|c|c|}
\hline & \multirow[b]{2}{*}{$\begin{array}{c}\text { Control Mean } \\
\text { (1) }\end{array}$} & \multicolumn{2}{|c|}{ Intent-To-Treat Difference } \\
\hline & & $\begin{array}{c}\text { Exp - Control } \\
\text { (2) }\end{array}$ & $\begin{array}{l}\text { Sec8 - Control } \\
\text { (3) }\end{array}$ \\
\hline \multicolumn{4}{|l|}{ A. Mobility } \\
\hline Subsidized move through MTO program & .000 & $\begin{array}{l}.479 * * \\
(.036)\end{array}$ & $\begin{array}{l}.619 * * \\
(.047)\end{array}$ \\
\hline Any residential move out of Boston city limits & .049 & $\begin{array}{l}.234 * * \\
(.035)\end{array}$ & $\begin{array}{l}.069 * * \\
(.035)\end{array}$ \\
\hline $\begin{array}{l}\text { Any residential move out of original housing } \\
\text { project }\end{array}$ & .271 & $\begin{array}{l}.325^{* *} \\
(.049)\end{array}$ & $\begin{array}{l}.414 * * \\
(.057)\end{array}$ \\
\hline \multicolumn{4}{|l|}{ B. Census tract characteristics } \\
\hline Poverty rate & .359 & $\begin{array}{l}-.122 * * \\
(.014)\end{array}$ & $\begin{array}{l}-.100 * * \\
(.016)\end{array}$ \\
\hline Welfare receipt & .294 & $\begin{array}{l}-.097 * * \\
(.012)\end{array}$ & $\begin{array}{l}-.066 * * \\
(.013)\end{array}$ \\
\hline Female-headed households & .531 & $\begin{array}{l}-.136 * * \\
(.016)\end{array}$ & $\begin{array}{l}-.091 * * \\
(.018)\end{array}$ \\
\hline Managerial and professional workers & .206 & $\begin{array}{l}.029 * * \\
(.007)\end{array}$ & $\begin{array}{l}.022 * * \\
(.008)\end{array}$ \\
\hline Education beyond high school degree & .289 & $\begin{array}{l}.064 * * \\
(.013)\end{array}$ & $\begin{array}{l}.066^{* * *} \\
(.015)\end{array}$ \\
\hline Speak almost no English & .097 & $\begin{array}{l}-.025 * * \\
(.007)\end{array}$ & $\begin{array}{l}.000 \\
(.009)\end{array}$ \\
\hline Hispanic & .218 & $\begin{array}{l}-.056 * * \\
(.017)\end{array}$ & $\begin{array}{l}-.018 \\
(.021)\end{array}$ \\
\hline Black & .449 & $\begin{array}{l}-.095 * * \\
(.035)\end{array}$ & $\begin{array}{l}-.057 \\
(.040)\end{array}$ \\
\hline \multicolumn{4}{|l|}{ C. Test scores of school child attends } \\
\hline Reading test score percentile of school & .083 & $\begin{array}{l}.076 * * \\
(.021)\end{array}$ & $\begin{array}{l}.026 \\
(.022)\end{array}$ \\
\hline Math test score percentile of school & .099 & $\begin{array}{l}.061 * * \\
(.022)\end{array}$ & $\begin{array}{l}.027 \\
(.025)\end{array}$ \\
\hline
\end{tabular}

Note: Intent-To-Treat Difference is based on equation (2). Standard errors are reported in parentheses, adjusted for household level clustering; $*=\mathrm{p}$-value $<.1 ; * *=\mathrm{p}$-value < .05. Data in Panels A and B are from the 1990 Census. In Panel C, percentiles are weighted to represent fraction of Massachusetts students in schools with average test score below average score of school child attends, based on the 1994 Massachusetts Educational Assessment Program data from the Massachusetts Department of Education. Sample size is 525 households (Exp: 236; Sec8: 113; Control: 176) for Panels A and B, and 408 children ages 6-15 for Panel C. 
TABle 5 - Distribution SHARES OF CENSUS TRACt Poverty RATES FROM MTO-BOSTON FOLLOW-UP SURVEY

\begin{tabular}{|c|c|c|c|c|c|c|c|}
\hline \multirow[b]{2}{*}{ Poverty Rate } & \multicolumn{2}{|c|}{ Overall } & \multirow{2}{*}{$\begin{array}{c}\begin{array}{c}\text { No Subsidized Move } \\
\text { and Overall }\end{array} \\
\begin{array}{c}\text { Control } \\
(3)\end{array} \\
\end{array}$} & \multicolumn{2}{|c|}{$\begin{array}{l}\text { No Subsidized Move } \\
\text { through MTO program }\end{array}$} & \multicolumn{2}{|c|}{$\begin{array}{c}\text { Subsidized Move } \\
\text { through MTO program }\end{array}$} \\
\hline & $\begin{array}{l}\operatorname{Exp} \\
(1)\end{array}$ & $\begin{array}{c}\text { Sec8 } \\
(2)\end{array}$ & & $\begin{array}{l}\text { Exp } \\
(4)\end{array}$ & $\begin{array}{l}\operatorname{Sec} 8 \\
(5)\end{array}$ & $\begin{array}{l}\text { Exp } \\
(6)\end{array}$ & $\begin{array}{l}\operatorname{Sec} 8 \\
(7)\end{array}$ \\
\hline $0-10$ & .362 & .134 & .018 & .029 & .068 & .724 & .175 \\
\hline $10-20$ & .113 & .242 & .110 & .080 & .026 & .150 & .374 \\
\hline $20-30$ & .151 & .294 & .190 & .196 & .162 & .102 & .376 \\
\hline $30-40$ & .068 & .078 & .088 & .109 & .082 & .024 & .075 \\
\hline $40+$ & .306 & .253 & .593 & .587 & .663 & .000 & .000 \\
\hline Mean & .237 & .259 & .359 & .362 & .370 & .100 & .190 \\
\hline $\begin{array}{l}\text { Share of } \\
\text { sample }\end{array}$ & .449 & .216 & .335 & .234 & .082 & .215 & .134 \\
\hline
\end{tabular}

Note: Sample size is 525 households. 
TABLE 6 - MTO-BOSTON BASELINE SURVEY DESCRIPTIVE STATISTICS

OF LEARNING AND BEHAVIOR ISSUES FOR CHILDREN AGES 6-15

\begin{tabular}{lcc}
\hline \hline & Boys & Girls \\
\hline If child has physical, emotional, or mental problems that: & & \\
$\quad$ require special medicine or equipment & .17 & .06 \\
make it hard to get to school or to play active sports or games & .08 & .06 \\
If child during past 2 years has gotten special help for: & & .22 \\
$\quad$ learning problems & .14 \\
$\quad$ behavioral or emotional problems & .10 & .04 \\
If child's school asked someone to come in and talk about problems with & .25 & .16 \\
$\quad$ schoolwork or behavior during past 2 years & & .06 \\
If child suspended or expelled from school during past 2 years & .03 \\
If child goes to special class for gifted students or does advanced work in any & .14 & .11 \\
$\quad$ subjects & & \\
\hline
\end{tabular}

Note: Sample is based on up to two randomly selected children per household (children in the sampling universe for the MTO-Boston Follow-up Survey). Means weighted as described in Section II. Missing values are imputed at nonmissing mean. Sample size is 296 boys (from 253 households) and 316 girls (from 268 households). 
TABLE 7 - IMPACT OF MTO-Boston On HeALTH of CHILDREN AgES 6-15

\begin{tabular}{|c|c|c|c|c|c|c|c|c|}
\hline & & \multirow[b]{2}{*}{$\begin{array}{c}\text { Control } \\
\text { Overall } \\
\text { Mean } \\
(1) \\
\end{array}$} & \multicolumn{3}{|c|}{ Experimental versus Control } & \multicolumn{3}{|c|}{ Section 8 Comparison versus Control } \\
\hline & & & $\begin{array}{c}\text { Intent-To- } \\
\text { Treat } \\
\text { Difference } \\
\text { (2) }\end{array}$ & $\begin{array}{l}\text { Treatment- } \\
\text { On-Treated } \\
\text { Difference } \\
\text { (3) }\end{array}$ & $\begin{array}{l}\text { Control } \\
\text { Complier } \\
\text { Mean } \\
\text { (4) }\end{array}$ & $\begin{array}{c}\text { Intent-To- } \\
\text { Treat } \\
\text { Difference } \\
(5)\end{array}$ & $\begin{array}{c}\text { Treatment- } \\
\text { On-Treated } \\
\text { Difference } \\
\text { (6) }\end{array}$ & $\begin{array}{c}\text { Control } \\
\text { Complier } \\
\text { Mean } \\
\text { (7) }\end{array}$ \\
\hline \multirow[t]{2}{*}{ Fraction of 7 behavior problems } & Boys & .326 & $\begin{array}{l}-.090 * * \\
(.041)\end{array}$ & $\begin{array}{l}-.184 * * \\
(.088)\end{array}$ & .436 & $\begin{array}{l}-.113 * * \\
(.053)\end{array}$ & $\begin{array}{l}-.160 * * \\
(.079)\end{array}$ & .450 \\
\hline & Girls & .193 & $\begin{array}{l}-.023 \\
(.030)\end{array}$ & $\begin{array}{l}-.046 \\
(.056)\end{array}$ & .197 & $\begin{array}{l}-.050 \\
(.034)\end{array}$ & $\begin{array}{l}-.078 \\
(.053)\end{array}$ & .230 \\
\hline \multirow[t]{2}{*}{$\begin{array}{l}\text { At least one close friend in } \\
\text { neighborhood }\end{array}$} & Boys & .747 & $\begin{array}{l}.009 \\
(.079)\end{array}$ & $\begin{array}{l}.018 \\
(.159)\end{array}$ & .766 & $\begin{array}{l}.019 \\
(.091)\end{array}$ & $\begin{array}{l}.026 \\
(.129)\end{array}$ & .689 \\
\hline & Girls & .823 & $\begin{array}{l}-.146^{* *} \\
(.064)\end{array}$ & $\begin{array}{l}-.282 * * \\
(.123)\end{array}$ & .982 & $\begin{array}{l}-.190 * * \\
(.080)\end{array}$ & $\begin{array}{l}-.297 * * \\
(.128)\end{array}$ & .976 \\
\hline \multicolumn{2}{|c|}{$\begin{array}{l}\text { If any injuries or accidents during past } 6 \\
\text { months that required medical attention }\end{array}$} & .105 & $\begin{array}{l}-.059 * * \\
(.027)\end{array}$ & $\begin{array}{l}-.118 * * \\
(.055)\end{array}$ & .160 & $\begin{array}{l}-.037 \\
(.033)\end{array}$ & $\begin{array}{l}-.059 \\
(.050)\end{array}$ & .137 \\
\hline \multicolumn{2}{|c|}{$\begin{array}{l}\text { If any asthma attacks requiring medical } \\
\text { attention during past } 6 \text { months }\end{array}$} & .098 & $\begin{array}{l}-.051 * \\
(.029)\end{array}$ & $\begin{array}{l}-.103 * \\
(.059)\end{array}$ & .158 & $\begin{array}{l}-.004 \\
(.037)\end{array}$ & $\begin{array}{l}-.010 \\
(.055)\end{array}$ & .109 \\
\hline \multicolumn{2}{|c|}{$\begin{array}{l}\text { If been to doctor for regular check-up or } \\
\text { immunization during past } 6 \text { months }\end{array}$} & .856 & $\begin{array}{l}-.043 \\
(.037)\end{array}$ & $\begin{array}{l}-.087 \\
(.077)\end{array}$ & .955 & $\begin{array}{l}-.071 \\
(.056)\end{array}$ & $\begin{array}{l}-.106 \\
(.081)\end{array}$ & .893 \\
\hline
\end{tabular}

Note: Intent-To-Treat (ITT) Difference in columns 2 and 5 is based on equation (2'), using OLS to control for the 24 household Baseline Survey characteristics from Table 2 , the 7 behavior and learning issues from Table 6, and indicators for child's year of age as of 9/1/97. Treatment-On-Treated (TOT) estimates in columns 3 and 6 use 2SLS (with same controls as ITT), and instrument treatment compliance with treatment assignment as in equation (3). Implied means for Control Compliers (who would have moved through the program if they had been assigned to a treatment group) are computed in columns 4 and 7 as the difference of the unconditional means of Treatment Compliers (who did move through the program) and the TOT estimates. Robust standard errors adjusted for household clustering are reported in parentheses; $*=\mathrm{p}-\mathrm{value}<.1 ; * *=\mathrm{p}-$ value $<.05$. The sample sizes for rows 1-7 respectively are $274,300,272,302,569,570$, and 566. 
TABLE 8 - IMPACT OF MTO-BOSTON ON SAFETY

\begin{tabular}{|c|c|c|c|c|c|c|c|}
\hline & \multirow[b]{2}{*}{$\begin{array}{c}\text { Control } \\
\text { Overall } \\
\text { Mean } \\
(1) \\
\end{array}$} & \multicolumn{3}{|c|}{ Experimental versus Control } & \multicolumn{3}{|c|}{ Section 8 Comparison versus Control } \\
\hline & & $\begin{array}{c}\text { Intent-To- } \\
\text { Treat } \\
\text { Difference } \\
(2)\end{array}$ & $\begin{array}{c}\text { Treatment- } \\
\text { On-Treated } \\
\text { Difference } \\
(3) \\
\end{array}$ & $\begin{array}{c}\text { Control } \\
\text { Complier } \\
\text { Mean } \\
(4) \\
\end{array}$ & $\begin{array}{c}\text { Intent-To- } \\
\text { Treat } \\
\text { Difference } \\
\quad(5)\end{array}$ & $\begin{array}{c}\text { Treatment- } \\
\text { On-Treated } \\
\text { Difference } \\
\quad(6) \\
\end{array}$ & $\begin{array}{c}\text { Control } \\
\text { Complier } \\
\text { Mean } \\
(7) \\
\end{array}$ \\
\hline $\begin{array}{l}\text { If streets near home are unsafe or very unsafe } \\
\text { during the day }\end{array}$ & .386 & $\begin{array}{l}-.144 * * \\
(.048)\end{array}$ & $\begin{array}{l}-.305 * * \\
(.110)\end{array}$ & .400 & $\begin{array}{l}-.063 \\
(.058)\end{array}$ & $\begin{array}{l}-.112 \\
(.095)\end{array}$ & .400 \\
\hline $\begin{array}{l}\text { If head or children seen people using or } \\
\text { selling drugs once a week or more }\end{array}$ & .359 & $\begin{array}{l}-.196 * * \\
(.045)\end{array}$ & $\begin{array}{l}-.408 * * \\
(.093)\end{array}$ & .432 & $\begin{array}{l}-.125 * * \\
(.054)\end{array}$ & $\begin{array}{l}-.215^{* *} \\
(.088)\end{array}$ & .398 \\
\hline $\begin{array}{l}\text { If head or children seen or heard gunfire once } \\
\text { a month or more }\end{array}$ & .205 & $\begin{array}{l}-.122 * * \\
(.037)\end{array}$ & $\begin{array}{l}-.260 * * \\
(.079)\end{array}$ & .260 & $\begin{array}{l}-.098 * * \\
(.045)\end{array}$ & $\begin{array}{l}-.166 * * \\
(.073)\end{array}$ & .232 \\
\hline $\begin{array}{l}\text { If child has seen someone with a weapon } \\
\text { during the past three months }\end{array}$ & .102 & $\begin{array}{l}-.071 * * \\
(.029)\end{array}$ & $\begin{array}{l}-.143 * * \\
(.059)\end{array}$ & .165 & $\begin{array}{l}-.034 \\
(.036)\end{array}$ & $\begin{array}{l}-.055 \\
(.055)\end{array}$ & .098 \\
\hline $\begin{array}{l}\text { If personal crime during past six months, } \\
\text { at least one child involved }\end{array}$ & .127 & $\begin{array}{l}-.059 * \\
(.031)\end{array}$ & $\begin{array}{l}-.125^{*} \\
(.066)\end{array}$ & .157 & $\begin{array}{l}-.030 \\
(.040)\end{array}$ & $\begin{array}{l}-.053 \\
(.065)\end{array}$ & .144 \\
\hline $\begin{array}{l}\text { If personal crime during past six months, } \\
\text { household head involved }\end{array}$ & .073 & $\begin{array}{l}.009 \\
(.029)\end{array}$ & $\begin{array}{l}.018 \\
(.062)\end{array}$ & .038 & $\begin{array}{l}-.035 \\
(.026)\end{array}$ & $\begin{array}{l}-.054 \\
(.043)\end{array}$ & .062 \\
\hline If property crime during past six months & .134 & $\begin{array}{l}-.070 * * \\
(.034)\end{array}$ & $\begin{array}{l}-.154 * * \\
(.074)\end{array}$ & .222 & $\begin{array}{l}-.089 * * \\
(.033)\end{array}$ & $\begin{array}{l}-.146^{* *} \\
(.057)\end{array}$ & .221 \\
\hline
\end{tabular}

Note: Intent-To-Treat Difference uses OLS to control for the 24 household Baseline Survey characteristics from Table 2; row 4 also includes the 7 behavior and learning variables in Table 6, and indicators for child's age and gender. Estimates of the Treatment-On-Treated Difference and the Control Compl ier Mean are computed as described in Table 7. Robust standard errors adjusted for household clustering are reported in parentheses; $*=p$-value $<.1 *^{* *}=$ p-value $<.05$. Sample sizes of households are 509 (row 1), 507 (row 2), 513 (row 3), and 519 (rows 5-7). Sample in row 4 is 558 children ages 6-15. 
TABLE 9 - IMPACT OF MTO-BOSTON ON ADULT HEALTH AND SOCIAL INTERACTIONS

\begin{tabular}{|c|c|c|c|c|c|c|c|}
\hline & \multirow[b]{2}{*}{$\begin{array}{l}\text { Control } \\
\text { Overall } \\
\text { Mean } \\
(1)\end{array}$} & \multicolumn{3}{|c|}{ Experimental versus Control } & \multicolumn{3}{|c|}{ Section 8 Comparison verus Control } \\
\hline & & $\begin{array}{l}\text { Intent-To- } \\
\text { Treat } \\
\text { Difference } \\
\quad(2) \\
\end{array}$ & $\begin{array}{l}\text { Treatment- } \\
\text { On-Treated } \\
\text { Difference } \\
\quad(3)\end{array}$ & $\begin{array}{l}\text { Control } \\
\text { Complier } \\
\text { Mean } \\
(4)\end{array}$ & $\begin{array}{l}\text { Intent-To- } \\
\text { Treat } \\
\text { Difference } \\
\quad(5) \\
\end{array}$ & $\begin{array}{l}\text { Treatment- } \\
\text { On-Treated } \\
\text { Difference } \\
\quad(6) \\
\end{array}$ & $\begin{array}{l}\text { Control } \\
\text { Complier } \\
\text { Mean } \\
(7)\end{array}$ \\
\hline Overall health is good or better & .578 & $\begin{array}{l}.115^{* *} \\
(.048)\end{array}$ & $\begin{array}{l}.239 * * \\
(.100)\end{array}$ & .460 & $\begin{array}{l}.162 * * \\
(.056)\end{array}$ & $\begin{array}{l}.264 * * \\
(.092)\end{array}$ & .523 \\
\hline $\begin{array}{l}\text { Calm \& peaceful "a good bit of the time" or } \\
\text { more often during past } 4 \text { weeks }\end{array}$ & .465 & $\begin{array}{l}.107 * * \\
(.050)\end{array}$ & $\begin{array}{l}.226^{* * *} \\
(.104)\end{array}$ & .390 & $\begin{array}{l}.138 * * \\
(.063)\end{array}$ & $\begin{array}{l}.229^{* *} \\
(.103)\end{array}$ & .429 \\
\hline $\begin{array}{l}\text { Happy "a good bit of the time" or more often } \\
\text { during the past four weeks }\end{array}$ & .561 & $\begin{array}{l}.066 \\
(.051)\end{array}$ & $\begin{array}{l}.134 \\
(.103)\end{array}$ & .493 & $\begin{array}{l}.049 \\
(.061)\end{array}$ & $\begin{array}{l}.083 \\
(.097)\end{array}$ & .573 \\
\hline $\begin{array}{l}\text { Predicted probability of having had a Major } \\
\text { Depressive Episode }\end{array}$ & .253 & $\begin{array}{l}-.047 \\
(.039)\end{array}$ & $\begin{array}{l}-.098 \\
(.082)\end{array}$ & .343 & $\begin{array}{l}-.061 \\
(.047)\end{array}$ & $\begin{array}{l}-.100 \\
(.076)\end{array}$ & .232 \\
\hline $\begin{array}{l}\text { Visited w/friend or relative at own home at } \\
\text { least once a week in past month }\end{array}$ & .482 & $\begin{array}{l}-.058 \\
(.053)\end{array}$ & $\begin{array}{l}-.120 \\
(.109)\end{array}$ & .453 & $\begin{array}{l}-.058 \\
(.063)\end{array}$ & $\begin{array}{l}-.095 \\
(.101)\end{array}$ & .506 \\
\hline $\begin{array}{l}\text { Visited w/friend or relative at their home at } \\
\text { least once a week in the past month }\end{array}$ & .422 & $\begin{array}{l}.050 \\
(.054)\end{array}$ & $\begin{array}{l}.104 \\
(.113)\end{array}$ & .396 & $\begin{array}{l}.050 \\
(.063)\end{array}$ & $\begin{array}{l}.083 \\
(.102)\end{array}$ & .393 \\
\hline $\begin{array}{l}\text { Went to church or place of worship at least } \\
\text { once in the past month }\end{array}$ & .573 & $\begin{array}{l}.003 \\
(.053)\end{array}$ & $\begin{array}{l}.005 \\
(.111)\end{array}$ & .507 & $\begin{array}{l}-.046 \\
(.061)\end{array}$ & $\begin{array}{l}-.072 \\
(.099)\end{array}$ & .588 \\
\hline $\begin{array}{l}\text { Agree with: "Most people can be trusted" } \\
\text { versus "You can't be too careful in } \\
\text { dealing with people" }\end{array}$ & .078 & $\begin{array}{l}.052 \\
(.033)\end{array}$ & $\begin{array}{l}.110 \\
(.069)\end{array}$ & .037 & $\begin{array}{l}.017 \\
(.037)\end{array}$ & $\begin{array}{l}.032 \\
(.061)\end{array}$ & .037 \\
\hline
\end{tabular}

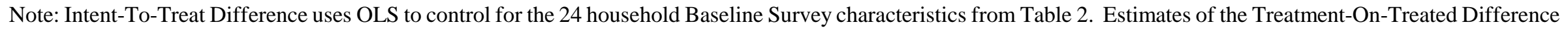

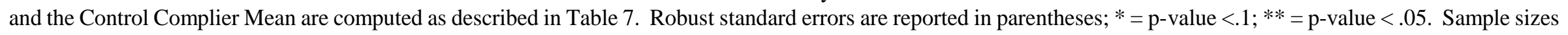
of households for rows 1-8 respectively are 511, 508, 506, 511, 509, 512, 510, and 499 . 
TABLE 10 - IMPACT OF MTO-BostON ON ADULT EMPLOYMENT

\begin{tabular}{|c|c|c|c|c|c|c|c|c|}
\hline & \multirow[b]{2}{*}{$\begin{array}{l}\text { Quarters } \\
\text { after } \\
\text { random } \\
\text { assignment }\end{array}$} & \multirow[b]{2}{*}{$\begin{array}{c}\text { Control } \\
\text { Overall } \\
\text { Mean } \\
(1) \\
\end{array}$} & \multicolumn{3}{|c|}{ Experimental versus Control } & \multicolumn{3}{|c|}{ Section 8 Comparison verus Control } \\
\hline & & & $\begin{array}{l}\text { Intent-To- } \\
\text { Treat } \\
\text { Difference } \\
(2)\end{array}$ & $\begin{array}{c}\text { Treatment- } \\
\text { On-Treated } \\
\text { Difference } \\
\quad(3)\end{array}$ & $\begin{array}{c}\text { Control } \\
\text { Complier } \\
\text { Mean } \\
(4)\end{array}$ & $\begin{array}{c}\text { Intent-To- } \\
\text { Treat } \\
\text { Difference } \\
\quad(5)\end{array}$ & $\begin{array}{l}\text { Treatment- } \\
\text { On-Treated } \\
\text { Difference } \\
\quad(6)\end{array}$ & $\begin{array}{c}\text { Control } \\
\text { Complier } \\
\text { Mean } \\
(7)\end{array}$ \\
\hline \multirow[t]{3}{*}{ If received AFDC/TANF } & 1 to 4 & .604 & $\begin{array}{l}-.000 \\
(.029)\end{array}$ & $\begin{array}{l}-.000 \\
(.062)\end{array}$ & .639 & $\begin{array}{l}-.005 \\
(.032)\end{array}$ & $\begin{array}{l}-.008 \\
(.052)\end{array}$ & .589 \\
\hline & 5 to 8 & .526 & $\begin{array}{l}-.000 \\
(.037)\end{array}$ & $\begin{array}{l}-.001 \\
(.079)\end{array}$ & .570 & $\begin{array}{l}-.023 \\
(.047)\end{array}$ & $\begin{array}{l}-.036 \\
(.074)\end{array}$ & .509 \\
\hline & 9 to 10 & .452 & $\begin{array}{l}.010 \\
(.040)\end{array}$ & $\begin{array}{l}.021 \\
(.085)\end{array}$ & .470 & $\begin{array}{l}-.031 \\
(.053)\end{array}$ & $\begin{array}{l}-.047 \\
(.083)\end{array}$ & .431 \\
\hline \multirow[t]{3}{*}{ If positive earnings } & 1 to 4 & .362 & $\begin{array}{c}.007 \\
(.033)\end{array}$ & $\begin{array}{c}.015 \\
(.071)\end{array}$ & .285 & $\begin{array}{c}.017 \\
(.040)\end{array}$ & $\begin{array}{c}.026 \\
(.064)\end{array}$ & .379 \\
\hline & 5 to 8 & .412 & $\begin{array}{l}-.002 \\
(.032)\end{array}$ & $\begin{array}{l}-.003 \\
(.077)\end{array}$ & .303 & $\begin{array}{l}.043 \\
(.046)\end{array}$ & $\begin{array}{l}.067 \\
(.072)\end{array}$ & .339 \\
\hline & 9 to 12 & .442 & $\begin{array}{l}-.006 \\
(.038)\end{array}$ & $\begin{array}{l}-.012 \\
(.081)\end{array}$ & .311 & $\begin{array}{l}.017 \\
(.045)\end{array}$ & $\begin{array}{l}.027 \\
(.072)\end{array}$ & .378 \\
\hline
\end{tabular}

Note: Intent-To-Treat Difference uses OLS to control for the 24 household Baseline Survey characteristics from Table 2, as well as indicators for calendar quarter and quarter since random assignment. Estimates of the Treatment-On-Treated Difference and the Control Complier Mean are computed as described in Table 7. Robust standard errors adjusted for household clustering are reported in parentheses. Sample size is 540 individuals, and four quarters per individual (except row 3 in which two quarters are available). Welfare data are from the Massachusetts Department of Transitional Assistance. Earnings data are from the Massachusetts Department of Revenue. 
TABLE 11 - SUMMARY OF IMPACTS OF MTO-BOSTON ON OUTCOMES

\begin{tabular}{|c|c|c|c|c|}
\hline & \multicolumn{2}{|c|}{ Experimental versus Control } & \multicolumn{2}{|c|}{ Section 8 versus Control } \\
\hline & $\begin{array}{c}\text { Control Complier } \\
\text { Mean } \\
\end{array}$ & $\begin{array}{l}\text { Relative Change for } \\
\text { Treatment Compliers }\end{array}$ & $\begin{array}{c}\text { Control Complier } \\
\text { Mean } \\
\end{array}$ & $\begin{array}{l}\text { Relative Change for } \\
\text { Treatment Compliers }\end{array}$ \\
\hline \multicolumn{5}{|l|}{ Child Health } \\
\hline Behavior problems index (boys) & .44 & $-42 \% * *$ & .45 & $-36 \% * *$ \\
\hline Behavior problems index (girls) & .20 & $-24 \%$ & .23 & $-34 \%$ \\
\hline If injury requiring medical attention & .16 & $-74 \% * *$ & .14 & $-43 \%$ \\
\hline If asthma attack requiring attention & .16 & $-64 \% *$ & .11 & $-9 \%$ \\
\hline \multicolumn{5}{|l|}{$\underline{\text { Safety }}$} \\
\hline Seen drugs in neighborhood & .43 & $-95 \% * *$ & .40 & $-54 \% * *$ \\
\hline Heard gunfire in neighborhood & .26 & $-100 \% * *$ & .24 & $-72 \% * *$ \\
\hline If child attacked, robbed, threatened & .16 & $-80 \% *$ & .15 & $-37 \%$ \\
\hline \multicolumn{5}{|l|}{$\underline{\text { Adult Health }}$} \\
\hline Overall health fair or poor & .54 & $-44 \% * *$ & .48 & $-55 \% * *$ \\
\hline Calm and peaceful some of the time or less & .61 & $-37 \% * *$ & .57 & $-40 \% * *$ \\
\hline Happy some of the time or less & .51 & $-27 \%$ & .43 & $-19 \%$ \\
\hline Predicted probability of major depressive episode & .34 & $-29 \%$ & .23 & $-43 \%$ \\
\hline \multicolumn{5}{|l|}{ Economic Self-sufficiency } \\
\hline If receiving TANF 9-10 quarters after enrollment & .47 & $+4.5 \%$ & .43 & $-11 \%$ \\
\hline If not employed 9-12 quarters after enrollment & .57 & $+2 \%$ & .50 & $-5 \%$ \\
\hline
\end{tabular}

Note: Control Complier Means and Relative Changes for Compliers (based on TOT Differences) are derived from coefficients in Tables 7-10.

$*=\mathrm{p}$-value $<.1 ; * *=\mathrm{p}$-value $<.05$ (based on TOT estimates). 